US Army Corps

of Engineers ${ }_{\circledast}$

Engineer Research and

Development Center

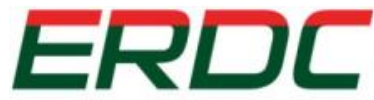

INNOVATIVE SOLUTIONS for a safer, better world

Wetlands Regulatory Assistance Program (WRAP)

A Review of Land and Stream Classifications in Support of Developing a National Ordinary High Water Mark (OHWM) Classification

Matthew K. Mersel, Lindsey E. Lefebvre,

August 2014

and Robert W. Lichvar

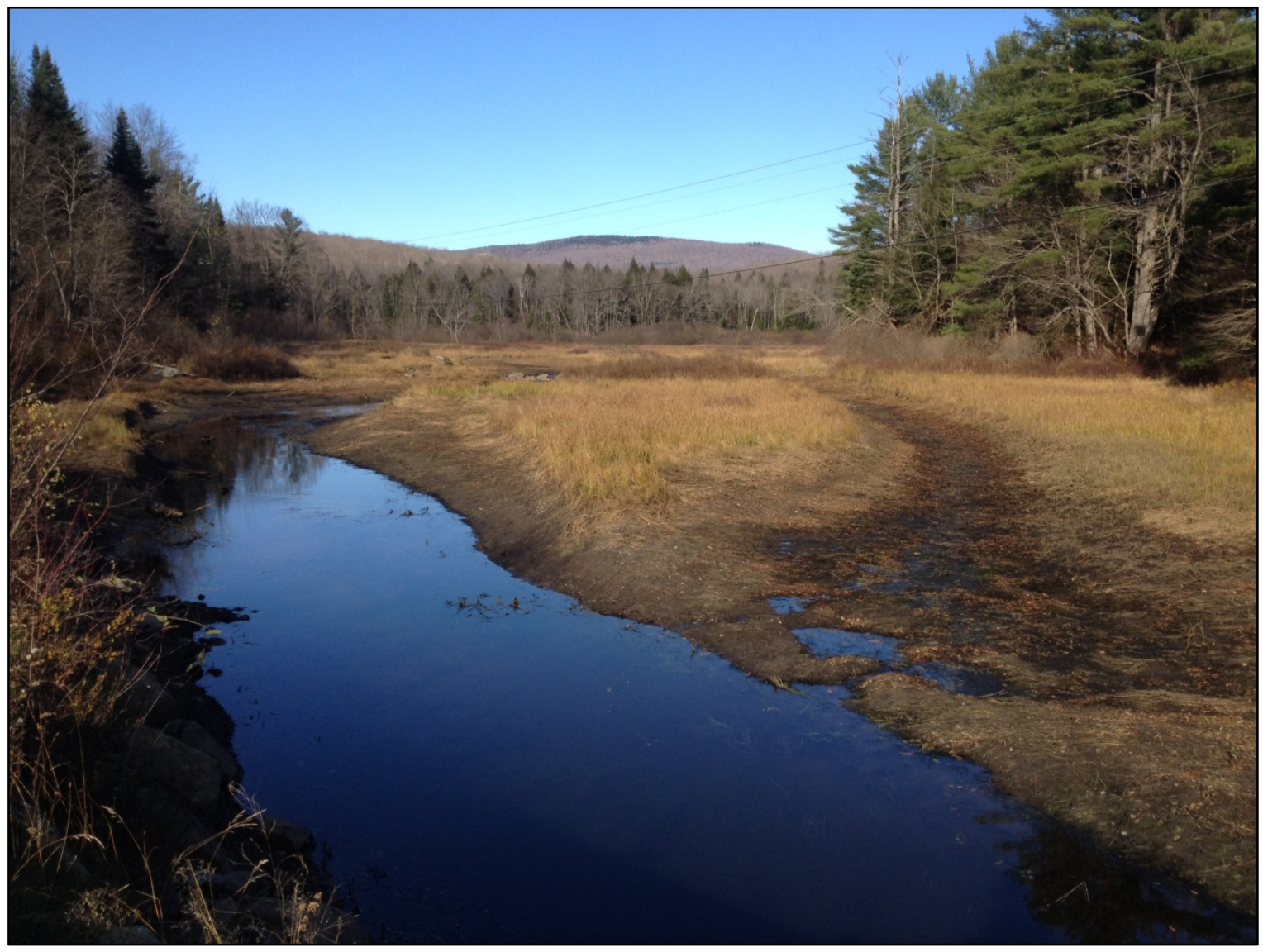


The U.S. Army Engineer Research and Development Center (ERDC) solves the nation's toughest engineering and environmental challenges. ERDC develops innovative solutions in civil and military engineering, geospatial sciences, water resources, and environmental sciences for the Army, the Department of Defense, civilian agencies, and our nation's public good. Find out more at www.erdc.usace.army.mil.

To search for other technical reports published by ERDC, visit the ERDC online library at http://acwc.sdp.sirsi.net/client/default. 


\section{A Review of Land and Stream Classifications in Support of Developing a National Ordinary High Water Mark (OHWM) Classification}

Matthew K. Mersel, Lindsey E. Lefebvre, and Robert W. Lichvar

Cold Regions Research and Engineering Laboratory (CRREL)

U.S. Army Engineer Research and Development Center

72 Lyme Road

Hanover, NH 03755

Final report

Approved for public release; distribution is unlimited.

Prepared for Wetlands Regulatory Assistance Program (WRAP)

U.S. Army Corps of Engineers

Vicksburg, MS 39180-6133 


\section{Abstract}

Under Section 404 of the Clean Water Act, the ordinary high water mark (OHWM) defines the lateral extent of federal jurisdiction in non-tidal waters of the United States in the absence of adjacent wetlands. Extensive research pertaining to identification and delineation of the OHWM in rivers and streams of the Arid West and Western Mountains, Valleys, and Coast regions has been conducted to better understand the occurrence and distribution of OHWM field indicators and to develop reliable methods for delineating the $\mathrm{OHWM}$ in these regions. Ongoing expansion of OHWM investigations into other regions of the U.S. stems from a need for nationally consistent and defensible OHWM delineation practices. A comprehensive framework is needed to foster the expansion of OHWM research and the development of delineation methods and indicators. A key element of this framework is the implementation of a classification system that allows for systematic sampling of the range of stream types and regions that exist throughout the U.S. This report reviews existing land and stream classifications and assesses the benefits and limitations of each approach for the purpose of developing a national OHWM classification. Additionally, it presents a preliminary version of a national OHWM classification.

DISCLAIMER: The contents of this report are not to be used for advertising, publication, or promotional purposes. Citation of trade names does not constitute an official endorsement or approval of the use of such commercial products. All product names and trademarks cited are the property of their respective owners. The findings of this report are not to be construed as an official Department of the Army position unless so designated by other authorized documents. 


\section{Contents}

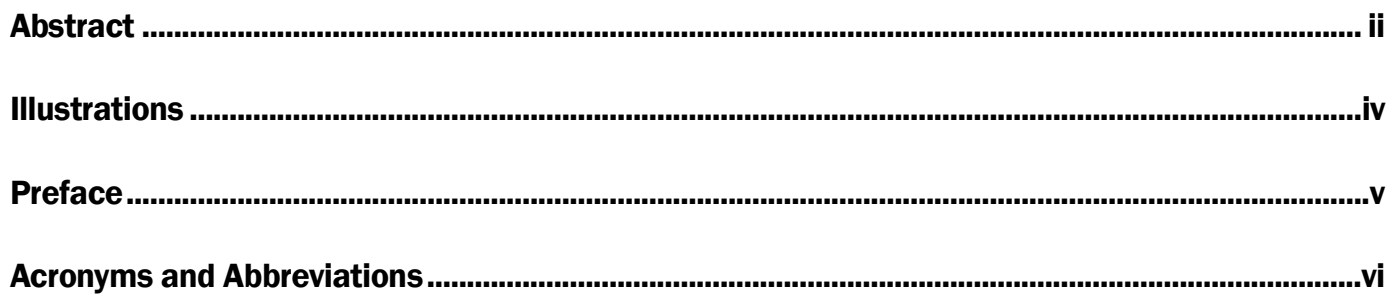

1 Introduction ............................................................................................................................. 1

1.1 Components of a national OHWM classification system........................................ 2

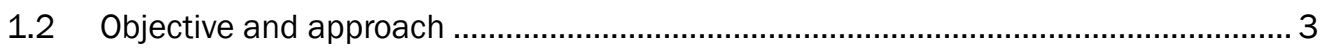

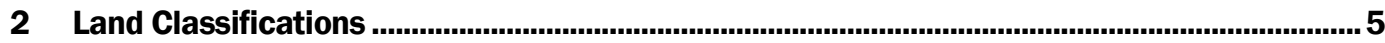

2.1 USDA Land Resource Regions and Major Land Resource Areas of the

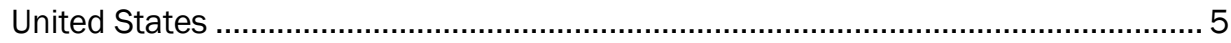

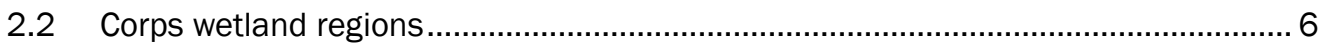

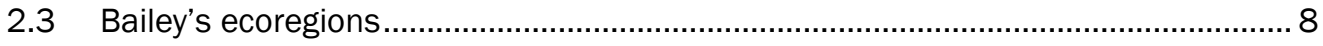

2.4 Omernik's ecoregions................................................................................... 9

2.5 Channel Form and Stream Ecosystem Models..................................................... 10

3 Stream Classifications..............................................................................................................13

3.1 Rosgen Classification of Natural Rivers ........................................................ 13

3.2 Montgomery and Buffington stream channel classification ................................ 16

3.3 Stream order classification ....................................................................... 18

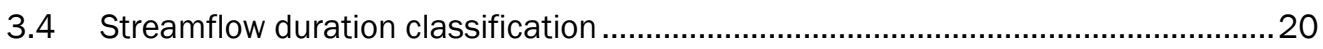

3.4.1 North Carolina Methodology for Identification of Intermittent and Perennial

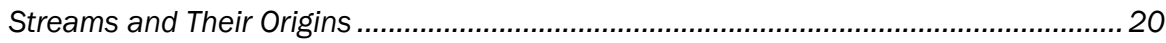

3.4.2 Streamflow Duration Assessment Method for Oregon ...............................................2 21

4 Land-Water Classifications..................................................................................................24

4.1 Stream Habitat Classification ............................................................................. 24

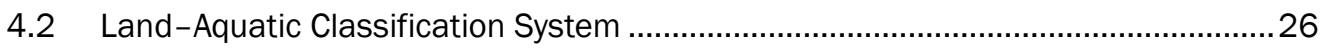

4.3 River Environment Classification ............................................................... 27

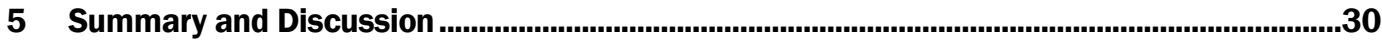

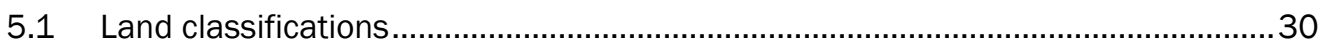

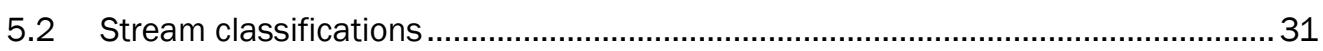

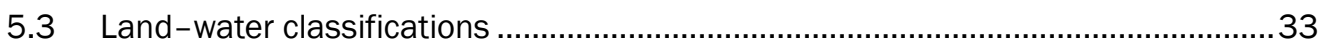

6 Proposed National OHWM Classification ............................................................................35

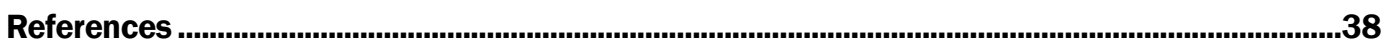

\section{Report Documentation Page}




\section{Illustrations}

\section{Figures}

1 Land Resource Regions overlain by NRCS regions............................................................ 6

2 Corps wetland regions, based on LRRs and MLRAs, developed for regionalization of the Wetland Delineation Manual .................................................................................

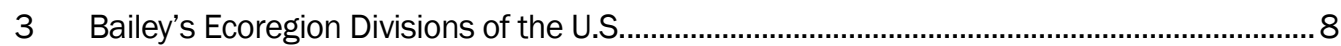

4 Omernik's Level III ecoregions of the U.S.......................................................................10

5 Channel Form and Stream Ecosystem Mode: (1) Glaciated Igneous Region, (2) Eastern Mountain Region, (3) Glaciated Interior Region, (4) Mid-Continent Region, (5) Eastern Coastal Region, (6) Ephemeral Region, and (7) Western Mountain Region

6 Level I stream types in the Rosgen Classification of Natural Rivers ...................................15

$7 \quad$ Example of the stream order classification developed by Strahler ......................................19

8 Streamflow Duration Assessment Method for Oregon …….................................................22

\section{Tables}

1 Descriptions of the seven stream regions identified in the Channel Form and Stream Ecosystem Model developed by Brussock et al. (1985) ........................................12

2 Montgomery and Buffington classification categories at the channel-reach scale............18

3 Methodology in North Carolina for identifying intermittent and perennial streams

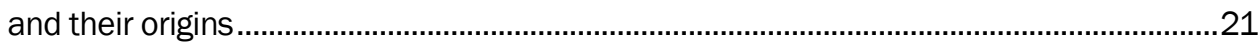

4 Stream Habitat Classification categories .............................................................................25

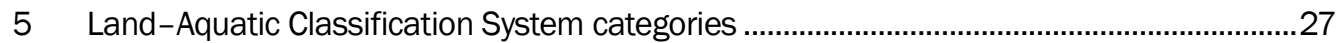

6 River Environment Classification categories ...................................................................29

7 Example of the proposed national OHWM classification in the Northcentral and Northeast region 


\section{Preface}

Support and funding for this project were provided by the U.S. Army Corps of Engineers (USACE) Headquarters through the Wetlands Regulatory Assistance Program (WRAP). The authors acknowledge and appreciate their interest and support and that of Margaret Gaffney-Smith, Karen Mulligan, and Stacey J ensen of the Headquarters Regulatory Program and Sally Yost of the U.S. Army Engineer Research and Development Center Environmental Laboratory (ERDC-EL).

This report was prepared by Matthew K. Mersel, Lindsey E. Lefebvre, and Robert W. Lichvar (Remote Sensing/ GIS and Water Resources Branch, Timothy Pangburn, Chief), ERDC Cold Regions Research and Engineering Laboratory (CRREL). At the time of publication, Dr. J ustin Berman was Chief of the Research and Engineering Division. The Deputy Director of ERDC-CRREL was Dr. Lance Hansen, and the Director was Dr. Robert Davis.

Peer reviews were provided by J ennifer Gillrich, Physical Scientist, CRREL, and J eanne Roningen, Research Physical Scientist, CRREL.

COLJ effrey R. Eckstein was the Commander of ERDC, and Dr. J effery P. Holland was the Director. 


\section{Acronyms and Abbreviations}

$\begin{array}{ll}\text { CRREL } & \text { U.S. Army Cold Regions Research and Engineering Laboratory } \\ \text { CWA } & \text { Clean Water Act } \\ \text { EL } & \text { Environmental Laboratory } \\ \text { EPA } & \text { U.S. Environmental Protection Agency } \\ \text { ERDC } & \text { Engineer Research and Development Center } \\ \text { GIS } & \text { Geographic Information Systems } \\ \text { LLR } & \text { Land Resource Region } \\ \text { LWD } & \text { Large, Woody Debris } \\ \text { MLRA } & \text { Major Land Resource Area } \\ \text { NCDWQ } & \text { North Carolina Department of Water Quality } \\ \text { NRCS } & \text { Natural Resources Conservation Service } \\ \text { OHWM } & \text { Ordinary High Water Mark } \\ \text { REC } & \text { River Environment Classification } \\ \text { USACE } & \text { U.S. Army Corps of Engineers } \\ \text { WRAP } & \text { Wetlands Regulatory Assistance Program } \\ & \end{array}$




\section{Introduction}

Federal regulations define the ordinary high water mark (OHWM) as "that line on the shore established by the fluctuations of water and indicated by physical characteristics such as a clear, natural line impressed on the bank, shelving, changes in the character of soil, destruction of terrestrial vegetation, the presence of litter and debris, or other appropriate means that consider the characteristics of the surrounding areas" (U.S. Congress 1986). Under Section 404 of the Clean Water Act (CWA), the OHWM defines the lateral extent of federal jurisdiction in non-tidal waters of the United States in the absence of adjacent wetlands (U.S. Congress 1977). Thus, consistent, repeatable, and defensible OHWM delineation practices are essential for proper implementation of the CWA.

Fluvial systems are inherently dynamic, and physical and biological field indicators of the OHWM may vary both spatially (e.g., between different regions, landscapes, and stream types) and temporally (e.g., seasonally, between flow events, and at longer time scales), thus introducing challenges to accurate and consistent delineation of the OHWM in rivers and streams throughout the U.S. Extensive research pertaining to the OHWM in non-perennial (i.e., ephemeral and intermittent) stream systems in the Arid West Region (e.g., Lichvar and Wakeley 2004; Lichvar et al., 2006; 2009; Curtis et al. 2011; Lefebvre et al. 2013a, 2013b) and in the Western Mountains, Valleys, and Coast Region (e.g., Mersel et al. 2014) has been conducted to better understand the field indicators used to identify the $\mathrm{OHWM}$ and to develop reliable methods for delineating the OHWM in these regions. This work has led to the development of OHWM delineation manuals for non-perennial stream systems in both regions (Lichvar and McColley 2008; Mersel and Lichvar, 2014). Supported by extensive field research, these manuals emphasize the use of macro-scale geomorphic features in combination with sediment and vegetation characteristics and other supporting features to identify and delineate the OHWM. These efforts notwithstanding, the spatial and temporal variability of OHWM indicators remains unexplored for most stream types in most regions of the U.S.

Ongoing expansion of OHWM investigations into other regions of the U.S. stems from a need for nationally consistent and defensible regulatory 
practices. To foster the expansion of OHWM studies and delineation guidance, a comprehensive framework is needed. A key element of this framework is to develop a national OHWM classification system that allows for systematic sampling of the range of stream types and regions that exist throughout the U.S.

\subsection{Components of a national OHWM classification system}

A national OHWM classification system must be detailed enough to encompass the full range of hydrologic and geomorphic variability that exists in rivers and streams throughout the U.S. This must be balanced, however, by the practical limitations of sampling on a national scale. That is, a national OHWM classification cannot be overly detailed such that sampling for each stream type and region is logistically infeasible.

Important variables related to the distribution of different stream types or characteristics and those potentially influencing the occurrence and distribution of OHWM indicators and characteristics include landscape position (e.g., elevation, slope, valley shape, etc.), vegetation characteristics (e.g., density, maturity, species composition, etc.), and sediment characteristics (e.g., composition, texture, soil development, etc.), which in turn are driven largely by climate and geology (Lotspeich and Platts 1982; Bailey 1983; Brussock et al. 1985; Omernik 1987; Snelder and Biggs 2002; Lichvar et al. 2006, 2009; Mersel et al. 2014). Other variables that are potentially relevant to the occurrence and distribution of OHWM indicators include streamflow duration (i.e., perennial, intermittent, or ephemeral streamflow) and geomorphic characteristics, such as channel size and pattern (e.g., braided, single thread, etc.) or bedform type (e.g., step-pool, pool-riffle, etc.). Additionally, anthropogenic forces, such as land use and hydromodification, may potentially influence $\mathrm{OHWM}$ characteristics.

One option for developing a national OHWM classification is to emphasize geographic variability in factors that potentially influence stream characteristics (e.g., climate, topography, and geology), thus allowing for sampling of the OHWM in defined geographic regions. A geographic component is desirable in a national OHWM classification because stream characteristics, and thus potentially OHWM indicators, vary greatly between different regions of the country (Brussock et al. 1985). Streams in the Arid West, for example, exhibit substantially different channel forms (e.g., compound or multi-threaded channel forms) in response to process- 
es and hydrologic regimes that differ considerably from most other parts of the U.S. (Graf 1988).

Another option is to emphasize variability in stream characteristics (e.g., stream form, process, function, streamflow duration, etc.); thus, sampling of the OHWM could be structured by stream type or category. A stream characteristic component is desired because even within a given geographic region there exists substantial variability in stream form, process, function, or other factors potentially related to OHWM indicator occurrence and distribution (Brussock et al. 1985). For example, mountain streams and low-gradient rivers commonly take on different forms from one another in response to differing hydrogeomorphic processes even within a fairly homogenous climatic region.

A third and most likely option for a national OHWM classification is to include elements of both geography and stream characteristics, thus allowing for sampling of a range of stream types or categories within distinct geographic regions.

\subsection{Objective and approach}

With the above classification criteria in mind, the objective of this report is to determine the most appropriate factors to include in a national OHWM classification. To that end, this report reviews existing land and stream classifications and assesses the benefits and limitations of each approach for the purpose of developing a national OHWM classification. This review includes only those classification systems thought to have some potential applicability to OHWM classification. This review includes land classifications (Section 2), which distinguish between different regions based on one or more physiographic or ecological factors; stream classifications (Section 3), which distinguish between different stream types based on one or more characteristics of streams; and land- water classifications (Section 4), which are hybrid approaches that incorporate elements of both land and stream classification.

A national OHWM classification can be developed either by adopting an existing classification system in whole or in part or by adapting or combining one or more existing classifications to meet the particular needs of a national OHWM classification. Following a review of various land, stream, and hybrid classifications, Section 5 summarizes and discusses the benefits and limitations of the reviewed approaches. Section 6 concludes with 
an outline of a preliminary national OHWM classification and provides recommendations for its use and implementation. 


\section{Land Classifications}

Land classifications divide the land surface into distinct units based on any number of factors that control and influence the physical, chemical, or biological attributes of a given location. Given the strong geographic component to the distribution of stream types and hydrologic regimes throughout the U.S., the inclusion of a geographic element into a national OHWM classification is logical. Additionally, incorporating elements of land classification into a national OHWM classification would allow sampling and subsequent technical guidance to be more regionally focused.

For the purposes of this report, only those land classifications that incorporate factors with potential relevance to the spatial distribution of different stream types or OHWM indicators are included. To that end, this section summarizes several widely used land classifications and discusses the benefits and limitations of each in the context of developing a national OHWM classification. The five land classifications included here are all geographically dependent in that they are fixed to a particular geographic

area and define explicit geographic regions. Several of these classifications use a hierarchical approach (i.e., they categorize the landscape at multiple spatial scales) while others are limited to a single spatial scale.

\subsection{USDA Land Resource Regions and Major Land Resource Areas of the United States}

Land Resource Regions (LRRs) and Major Land Resource Areas (MLRAs) are components of a hierarchical land classification that the U.S. Department of Agriculture (USDA) Natural Resources Conservation Service (NRCS) originally developed to aid in decision making pertaining to national and regional agricultural concerns (USDA 2006). LRRs approximate broad agricultural market regions based on characteristics of the soils, climate, land use, water resources, elevation, topography, and potential natural vegetation or crop types (Figure 1). LRRs are typically used for larger-scale regional and national management and planning purposes. MLRAs further delineate LRRs based on similar criteria and are typically used for smaller-scale planning purposes.

LRRs and MLRAs incorporate many physiographic and environmental factors that are potentially related to the geographic distribution of stream 
types (e.g., soils, climate, vegetation, and topography) and thus are potentially relevant to geographic differences with respect to OHWM indicators. This classification system has the advantage of being well established and familiar to many federal and state agency personnel. MLRAs and even LRRs are perhaps overly detailed for OHWM classification purposes and would likely need to be grouped into larger regions more suitable to the purposes of a national OHWM classification. The hierarchical structure of this classification would allow further delineation of broad geographic regions if necessary.

Figure 1. Land Resource Regions overlain by NRCS regions (USDA 1998).

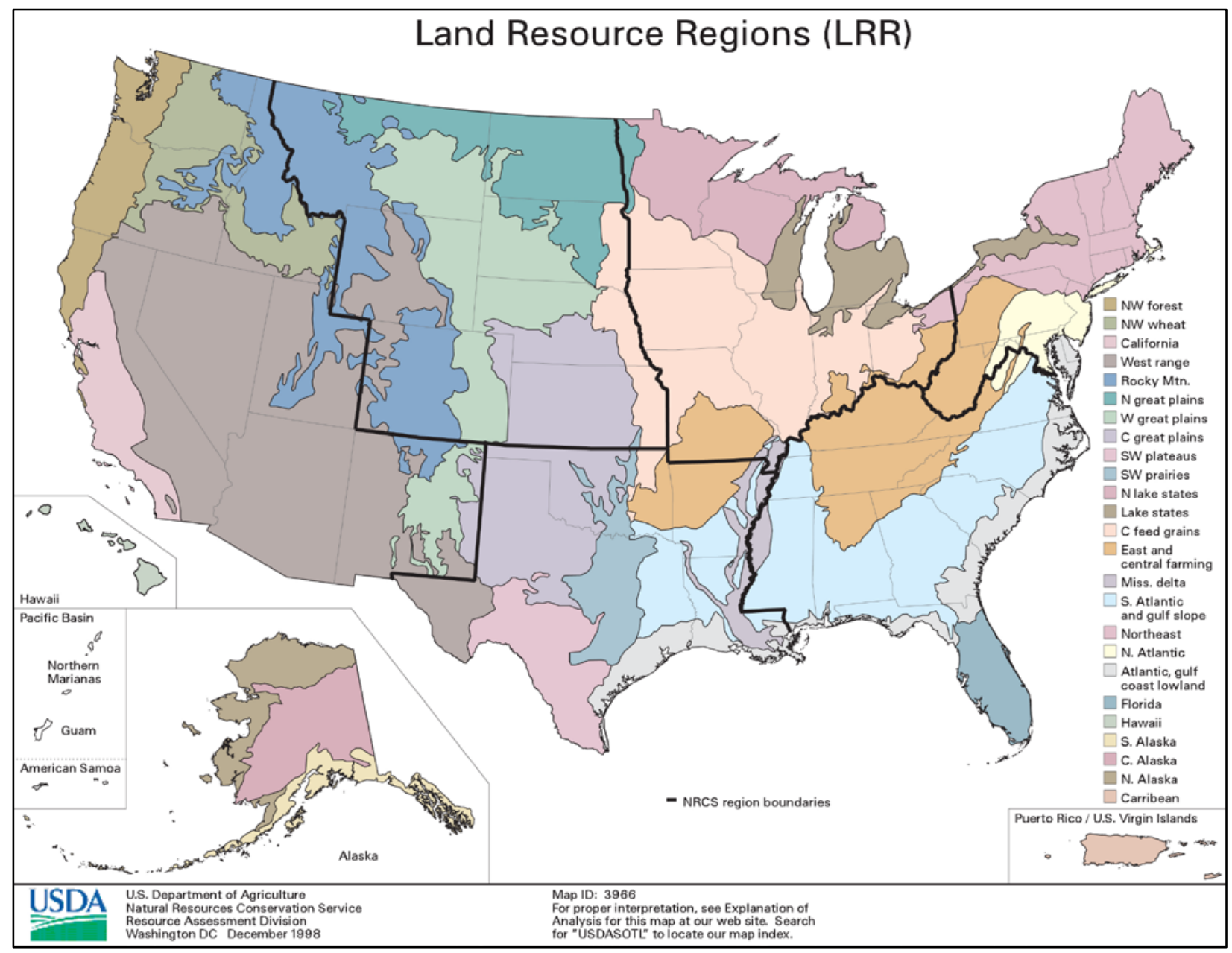

\subsection{Corps wetland regions}

In 2002, the U.S. Army Corps of Engineers (USACE or Corps) initiated the development of regionalized versions of the 1987 Corps Wetland Delineation Manual (Environmental Laboratory 1987) to provide increased sensitivity to regional differences in climate, hydrologic and geomorphic condi- 
tions, and other wetland characteristics (Wakeley 2002). The U.S. was classified into 10 regions (Figure 2) for the purpose of developing regionspecific wetland delineation guidance (Berkowitz 2011). USDA LRRs served as the basis for this classification and were aggregated into broader regions that reflect variability in wetland characteristics and indicators. Each of the 10 Corps wetland regions has its own unique, regionally focused supplement to the 1987 national manual.

Figure 2. Corps wetland regions, based on LRRs and MLRAs, developed for regionalization of the Wetland Delineation Manual. The Alaska Region and the Hawaii and Pacific Islands Region are not shown here (from Berkowitz [2011]).

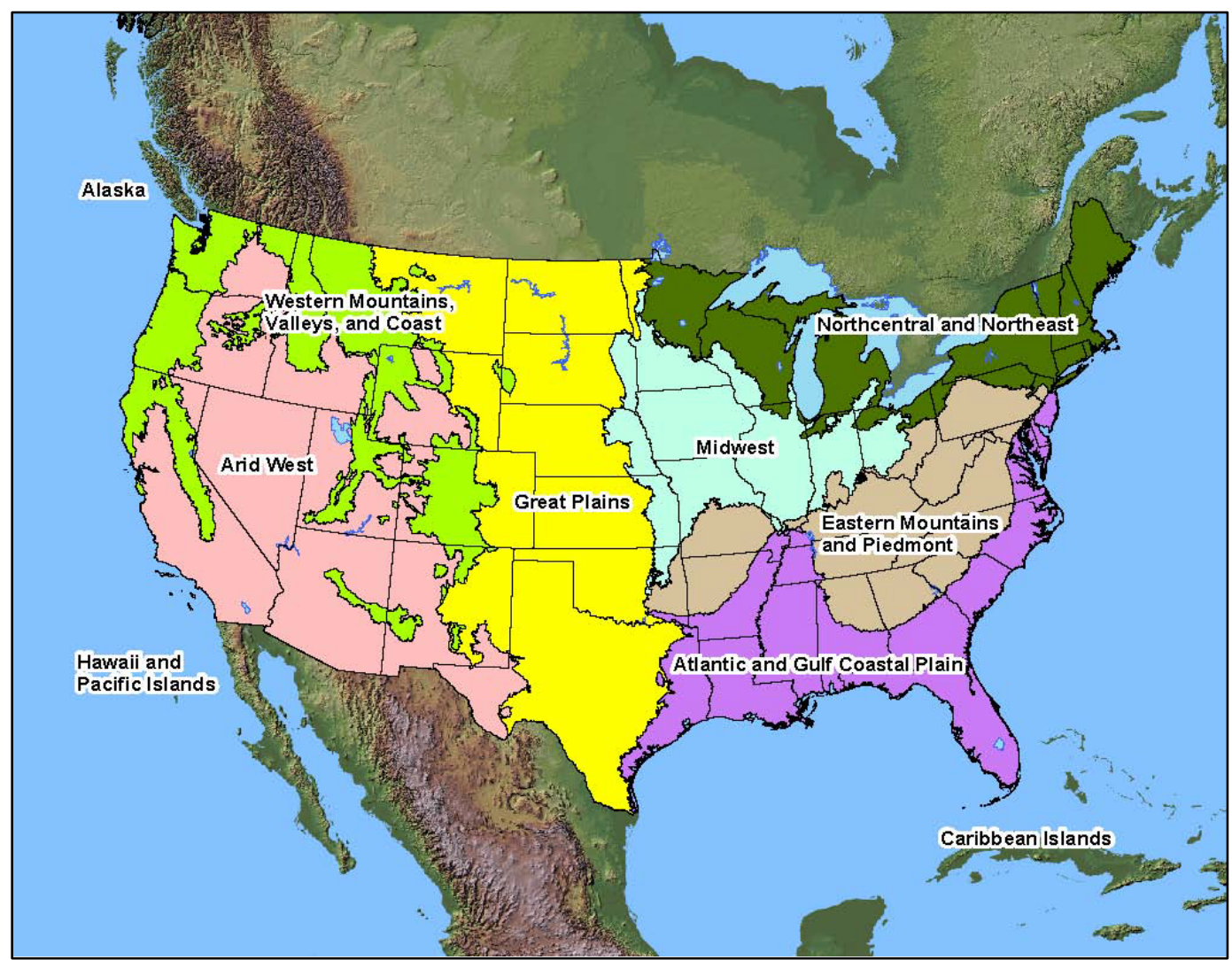

The Corps wetland regions serve as an example of adapting an existing classification system to meet the specific needs of a particular application, and a similar exercise could be undertaken for the purpose of developing a national OHWM classification. The Corps wetland regions could also be adopted without change, given that variability in wetland characteristics is driven by many of the same factors (e.g., climate, geology, and topography) that drive variability in stream characteristics and may therefore influence variability in OHWM indicators. This would have the additional 
advantage of maintaining continuity with respect to the regionalization of delineation guidance for both wetlands and streams.

\subsection{Bailey's ecoregions}

Bailey (1976) developed a map of the ecoregions of the U.S. as a counterpart to the regionalization of marine and estuarine systems developed by Cowardin et al. (1979) and also to support ecosystem management on land owned by the U.S. Forest Service. This widely used land classification system is based on geographical associations of similar-functioning ecosystems and divides the landscape into units that are important for the development of natural resources and for conservation purposes. Factors on which geographic divisions are based include climate, vegetation, soils, and land surface forms. Bailey (1983) provides a detailed description of the basis for Bailey's ecoregion map. Bailey's system uses a hierarchical approach, dividing the landscape first into broad domains and then into successively smaller divisions, provinces, and sections (Bailey 1980). It divides the continental U.S. into three domains (dry, humid temperate, and humid tropical) based on general climatic factors. The domains are spilt into 20 divisions based on similar climate, vegetation, and soils (Figure 3). Divisions are then further divided into 35 provinces based on finer-scale variability in climax vegetation composition. At the finest level in the classification are sections, which subdivide some provinces based on distinct terrain features and vegetation patterns.

Figure 3. Bailey's Ecoregion Divisions of the U.S. (Bailey 1995).

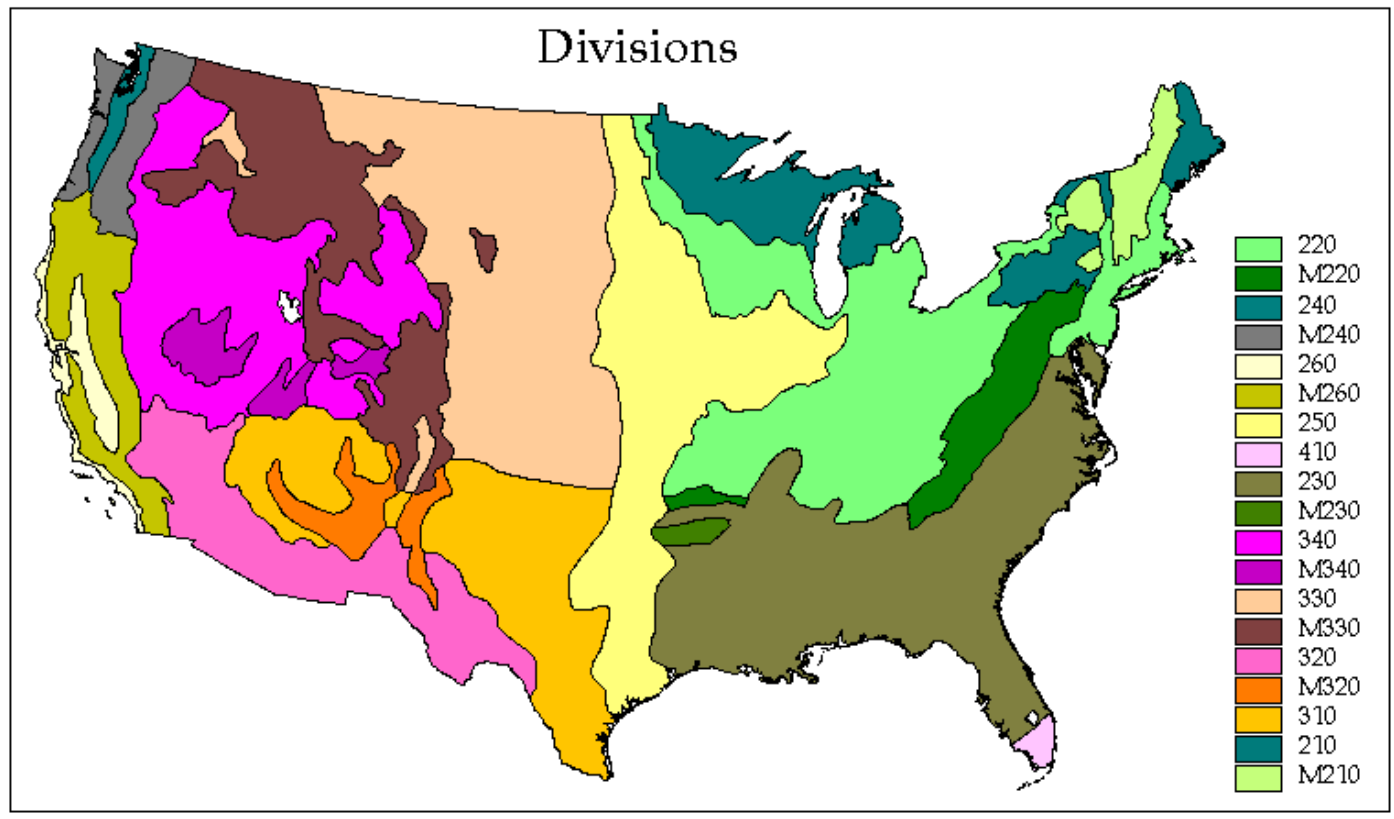


Bailey's ecoregions provide multiple levels of detail with which to partition the U.S. into discrete units. For the purposes of a national OHWM classification, domains are overly coarse while provinces and sections are overly detailed. Divisions provide the most appropriate level of detail (Figure 3) although some divisions would likely still need to be aggregated to reduce the number of regions. A potential option for incorporating this land classification into a national OHWM classification is to combine ecoregions at one or more levels of the classification hierarchy to develop unique regions that better reflect differences in stream characteristics or OHWM indicators.

\subsection{Omernik's ecoregions}

Omernik (1987) also devised a classification for ecoregions within the U.S. "to assist managers of aquatic and terrestrial resources in understanding the regional patterns of the realistically attainable quality of these resources" (Omernik 1987). Although originally designed for the regionalization of water resource management, Omernik's classification is based on patterns of terrestrial characteristics. Thus, the derived ecoregions reflect both aquatic and terrestrial ecosystems. Regional boundaries are based on patterns in climate, geology, soils, physiography, potential natural vegetation, and land use. Omernik's analysis used small-scale "component maps" of major land uses, classes of land-surface form, potential natural vegetation, and soils from multiple sources. It also used LRRs and MLRAs to confirm the accuracy of the component maps and to support the patterns that indicated ecoregions (Omernik 1987). This classification was subsequently adopted and refined by the U.S. Environmental Protection Agency (EPA) and is structured into four levels of increasing detail (Levels I- IV) (http://www.epa.gov/wed/pages/ecoregions.htm). Figure 4. Omernik's Level III Ecoregions of the U.S. is a map of the Level III classification for the conterminous U.S. This classification provides a framework for professionals to assess land and water relationships, to establish regional water quality standards, to locate potential field sites for monitoring or other purposes, and to determine the effects of anthropogenic impacts (Omernik 1987). 
Figure 4. Omernik's Level III ecoregions of the U.S. (EPA 2006).

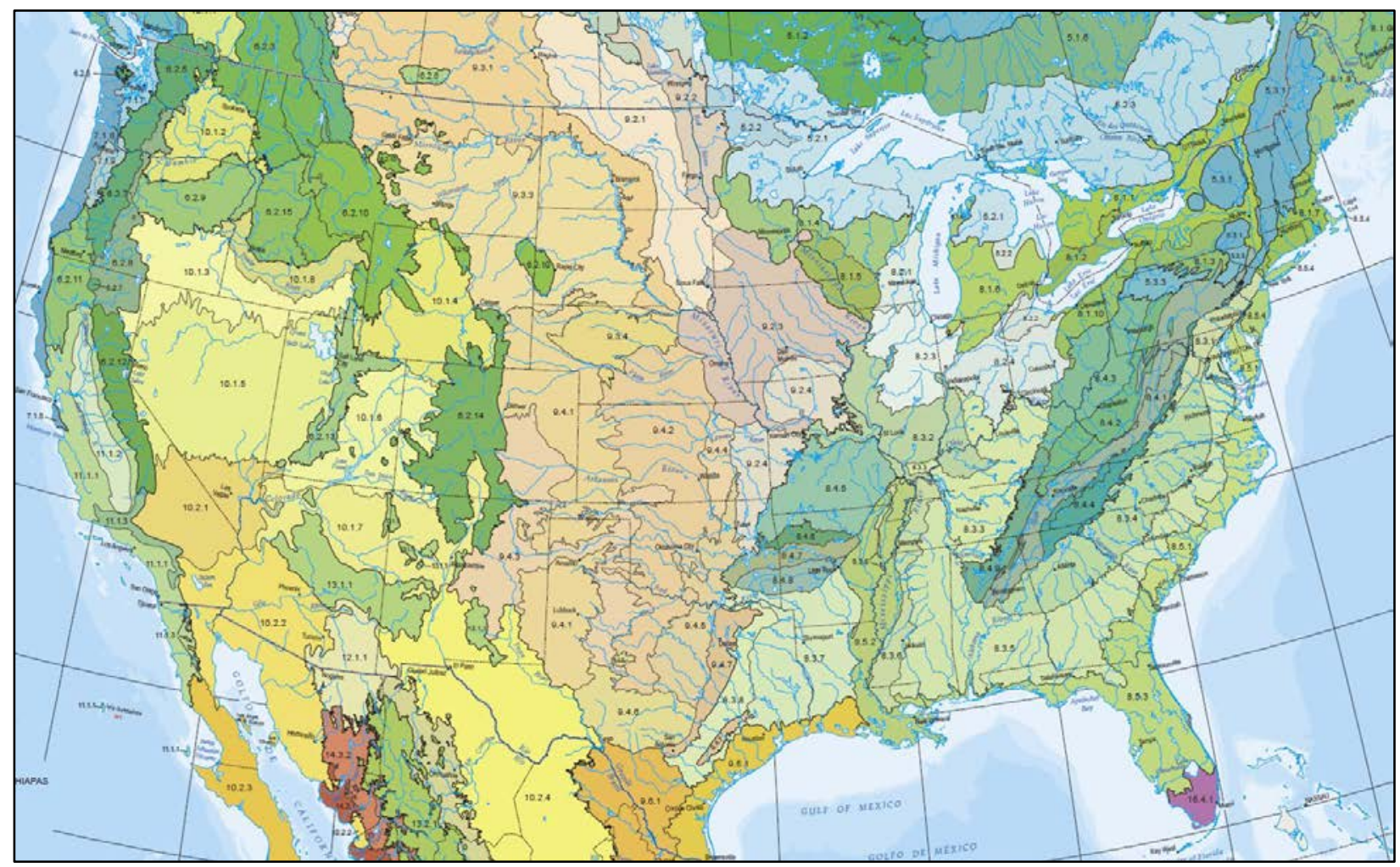

Omernik's ecoregion classification has many similarities to Bailey's in terms of the underlying variables and the hierarchical structure. Like Bailey's ecoregion classification, Omernik's ecoregions are either too coarse (Level I) or overly detailed (Levels II- IV) and do not explicitly represent distinct stream regions. Thus, Omernik's ecoregions would likely need to be grouped into classes that are more appropriate for a national OHWM classification and that reflect broader trends in stream characteristics.

\subsection{Channel Form and Stream Ecosystem Models}

Brussock et al. (1985) developed a land classification, based on river and stream habitat characteristics, called the Channel Form and Stream Ecosystem Model. This classification system emphasizes the role of channel form, both longitudinally and regionally, in the physical and community structure of the system. In this framework, channel form is considered in three broad classes of sedimentological settings-cobble and boulder bed channels, gravel bed channels, and sand bed channels. Channel form is in turn thought to be controlled by three physical factors-relief, lithology, and runoff. Brussock et al. (1985) integrated these controlling factors across the conterminous U.S. to derive seven distinct stream regions 
(Figure 5). Each region is considered in terms of the generalized longitudinal succession of stream channel form from the headwaters to the mouth. Channel form succession in each region is compared to that of the ideal longitudinal model in which high-gradient headwater streams, characterized by steep valley walls and coarse sediments, transition to lowgradient streams, characterized by broad valleys and fine-grained sediments. Table 1 summarizes the seven regions.

Figure 5. Channel Form and Stream Ecosystem Mode: (1) Glaciated Igneous Region, (2) Eastern Mountain Region, (3) Glaciated Interior Region, (4) Mid-Continent Region, (5) Eastern Coastal Region, (6) Ephemeral Region, and (7) Western Mountain Region (from Brussock et al. [1985]).

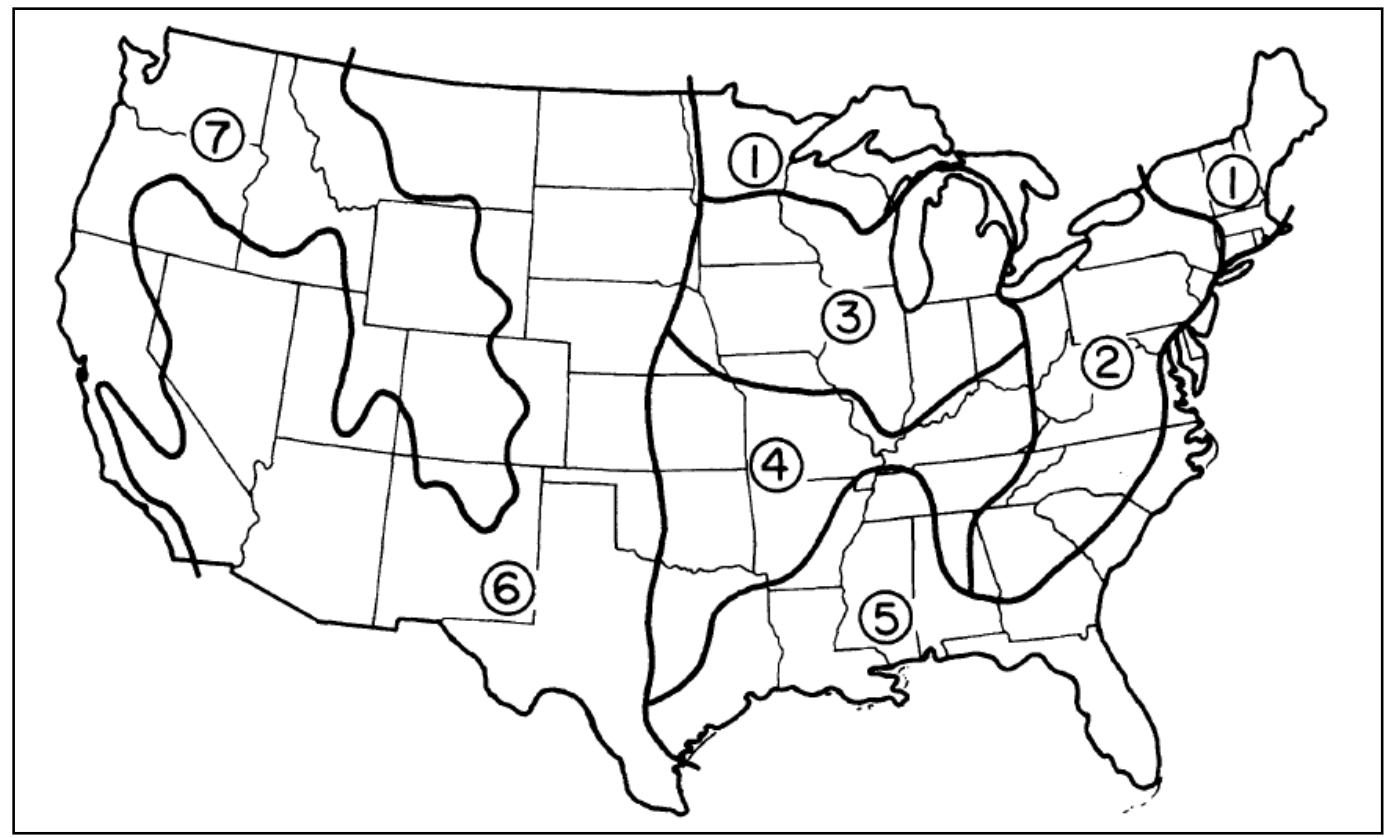

The Channel Form and Stream Ecosystem Model is different from the previously discussed land classifications in that it was explicitly designed for identifying patterns in stream characteristics, which makes it well suited for OHWM classification purposes. Additionally, the number of regions defined in this classification is well suited for national sampling purposes. A potential limitation of this classification, however, is that, unlike other classifications that use a hierarchical approach, this one does not provide for downscaling (i.e., the partitioning of one region into smaller regions based on some controlling factors) within a given stream region, should it become necessary. Moreover, this classification pertains only to the conterminous U.S., so the remaining states and territories would need to be grouped into additional regions. 
Table 1. Descriptions of the seven stream regions identified in the Channel Form and Stream Ecosystem Model developed by Brussock et al. (1985).

\begin{tabular}{|c|c|}
\hline Region & Description \\
\hline $\begin{array}{l}\text { (1) Glaciated } \\
\text { Igneous Region }\end{array}$ & $\begin{array}{l}\text { Includes the Adirondack Mountains; New England; and portions of northern Minnesota, } \\
\text { Wisconsin, and Michigan. This region is dominated by igneous and metamorphic rock, with } \\
\text { some sedimentary units and a generally thin cover of glacial drift with high amounts of large } \\
\text { cobbles and boulders. Relief in this region is generally low to moderate. Pool and riffle } \\
\text { structure is largely regulated by the location of boulders and debris accumulation. The } \\
\text { longitudinal profile of streams in this region fits well with the ideal model. }\end{array}$ \\
\hline $\begin{array}{l}\text { (2) Eastern } \\
\text { Mountain } \\
\text { Region }\end{array}$ & $\begin{array}{l}\text { Includes the Appalachian Mountains, Appalachian Plateau, and Catskill Mountains. It is } \\
\text { dominated by faulted igneous and metamorphic rocks and folded sediments in the } \\
\text { Appalachians and flat-lying sedimentary rocks in the Plateau and Catskills. Streams in this } \\
\text { region are similar in most respects to those in the Glaciated Igneous Region, but relief tends } \\
\text { to be greater in the Eastern Mountain Region. }\end{array}$ \\
\hline $\begin{array}{l}\text { (3) Glaciated } \\
\text { Interior Region }\end{array}$ & $\begin{array}{l}\text { Consists of the glaciated portion of the Central Lowlands. This region is overlain by a thick } \\
\text { mantle of heterogeneous, unconsolidated glacial drift. The combination of low relief and } \\
\text { abundant fine-grained material produces many sand bed channels that are similar in } \\
\text { appearance to many coastal streams. Regular pool and riffle structures develop where larger } \\
\text { particles are more abundant and relief is greater. Channelization and siltation are heavy in } \\
\text { this region due to extensive agricultural practices. Compared to the ideal model of longitudinal } \\
\text { channel form succession, the characteristics of downstream reaches are shifted upward in } \\
\text { this region. }\end{array}$ \\
\hline $\begin{array}{l}\text { (4) Mid- } \\
\text { Continent } \\
\text { Region }\end{array}$ & $\begin{array}{l}\text { Consists of the remainder of the Central Lowlands, excluding the High Plains. This region is } \\
\text { dominated by horizontal or gently sloping sedimentary rocks with low to moderate relief. This } \\
\text { region is similar in most respects to that of the Glaciated Interior Region but lacks the } \\
\text { extensive mantle of glacial drift. Pool and riffle structures tend to be well developed and } \\
\text { regularly spaced. These structures, typically characteristic of the mid-reaches of mountain } \\
\text { streams, extend into both the headwaters and the downstream reaches in this region, thus } \\
\text { representing a departure from the ideal model of channel form succession. }\end{array}$ \\
\hline $\begin{array}{l}\text { (5) Eastern } \\
\text { Coastal Region }\end{array}$ & $\begin{array}{l}\text { Includes a coastal band stretching from eastern Texas to New England. This region consists } \\
\text { largely of unconsolidated sands and gravels that thicken and slope gently towards the coast. } \\
\text { Sand-bed channels with little riffle-pool development dominate throughout the region. As with } \\
\text { the Glaciated Interior Region, the characteristics common to downstream reaches extend } \\
\text { nearer to the headwaters in this region. }\end{array}$ \\
\hline $\begin{array}{l}\text { (6) Ephemeral } \\
\text { Region }\end{array}$ & $\begin{array}{l}\text { Includes the Basin and Range Province and the High Plains of the western U.S. This region is } \\
\text { unique in the U.S. and represents a vast departure from the ideal model of channel form } \\
\text { succession. The region is extremely dry, contains sparse vegetation, and has an abundance of } \\
\text { sand-sized particles. As a result, ephemeral and intermittent streams dominate the region; } \\
\text { and channel form development differs greatly from the other regions. }\end{array}$ \\
\hline $\begin{array}{l}\text { (7) Western } \\
\text { Mountain } \\
\text { Region }\end{array}$ & $\begin{array}{l}\text { Includes the Rocky Mountains, the Coast Mountains, and the Columbia and Colorado } \\
\text { Plateaus. This region contains a mixture of igneous, metamorphic, and sedimentary rocks. } \\
\text { High relief and coarse materials are typical. Riffle and pool development is largely controlled } \\
\text { by the location of boulders and debris. Streams in this region fit well with the ideal model of } \\
\text { channel succession although the characteristics typical of headwater streams are shifted } \\
\text { downward in this region. }\end{array}$ \\
\hline
\end{tabular}




\section{Stream Classifications}

Stream classifications categorize rivers and streams based on any number of factors that control and influence their physical, chemical, or biological attributes. Each classification system has a specific intended purpose for use in different disciplines and applications, and thus each has advantages and disadvantages depending on the desired use. The intended purpose of a stream classification drives the scale, approach, and choice of characteristics by which to classify streams. Approaches to stream classification include those based on channel form, stream function, fluvial processes, habitat, streamflow duration, and hierarchy, among others.

A long history of stream classification dates back at least to Davis (1899), who classified streams based on their relative stage of development in the erosion cycle (youthful, mature, and old). Leopold and Wolman (1957) later classified streams into three categories-braided, meandering, or straight-describing generalized end members of channel form. These and other early classifications relied heavily on qualitative interpretations of stream characteristics while more recent classifications have placed greater emphasis on features that can be assessed quantitatively (e.g., Montgomery and Buffington 1993; Rosgen 1994). Buffington and Montgomery (2013) give a more comprehensive review of stream classifications both old and new.

Of the many and varied stream classifications that have been developed over the years, few have been designed to be universally applicable to any stream in any location. The stream classifications reviewed here include only those that can be applied at a national scale and that are based on factors that are potentially related to OHWM indicator occurrence and distribution (e.g., channel form, streamflow duration, stream order, etc.). The following subsections give a brief description of each classification system and discuss the benefits and limitations of each with respect to its applicability to a national OHWM classification.

\subsection{Rosgen Classification of Natural Rivers}

Perhaps the most commonly used and widely accepted stream classification system, particularly among state and federal agencies, is the Rosgen Classification of Natural Rivers (Rosgen 1994). This system was developed 
from channel measurements of 450 streams in multiple geographic settings and is perhaps the most comprehensive stream classification in terms of its universal applicability and the range of stream types and level of detail that it encompasses. The Rosgen classification was designed to allow users to predict a river's behavior from its appearance. In addition to classifying stream channels, this system provides a framework for interpreting response to disturbance, recovery potential after disturbance, sediment supply, susceptibility to bank erosion, and influence of vegetation on channel form in various stream channel types (Rosgen 1996).

The Rosgen Classification of Natural Rivers is divided into four hierarchical levels: (I) geomorphic characterization, (II) morphological description, (III) stream or condition, and (IV) validation and monitoring. Level I describes the general geomorphic characteristics of stream channels by their longitudinal profile, cross-section morphology, and plan view morphology and categorizes streams into the eight stream types illustrated in Figure 6. The longitudinal profile relates the stream gradient to channel bed features, the cross-section morphology describes the level of incision and relative size of the floodplain through width-to-depth ratios, and the plan view morphology describes the range of channel sinuosity from straight to meandering to braided channels. A majority of this information can be determined from topographic maps, landform maps, and aerial photography (Rosgen 1996).

Level II divides each of the Level I stream types into six categories based on the following parameters: number of channels (single or multiple), entrenchment ratio (ratio of the width of the flood-prone area to the bankfull width of the channel), width-to-depth ratio (ratio of the bankfull width to the bankfull mean depth), sinuosity (ratio of stream length to valley length), water surface slope, and dominant particle size.

Level III analyzes the condition of different stream types based on stability, potential, and function. Inputs to this analysis include vegetation; deposition pattern; debris occurrence; meander pattern; channel stability rating; sediment supply; bed stability; width-to-depth ratio; bank erosion potential; stream size and order; flow regime; and altered dimensions, patterns, profiles, and materials.

Lastly, Level IV is the field data verification of stream channels characterized in Levels II and III. The verification is based on multiple characteris- 
tics and measurements, including sediment measurements (bedload and suspended sediment), streamflow measurements (hydraulics, resistance, and hydrographs), stability (aggradation and degradation), sediment change in storage and size distribution, and bank erosion rates (time trends regarding stability).

Figure 6. Level I stream types in the Rosgen Classification of Natural Rivers (EPA 2008).

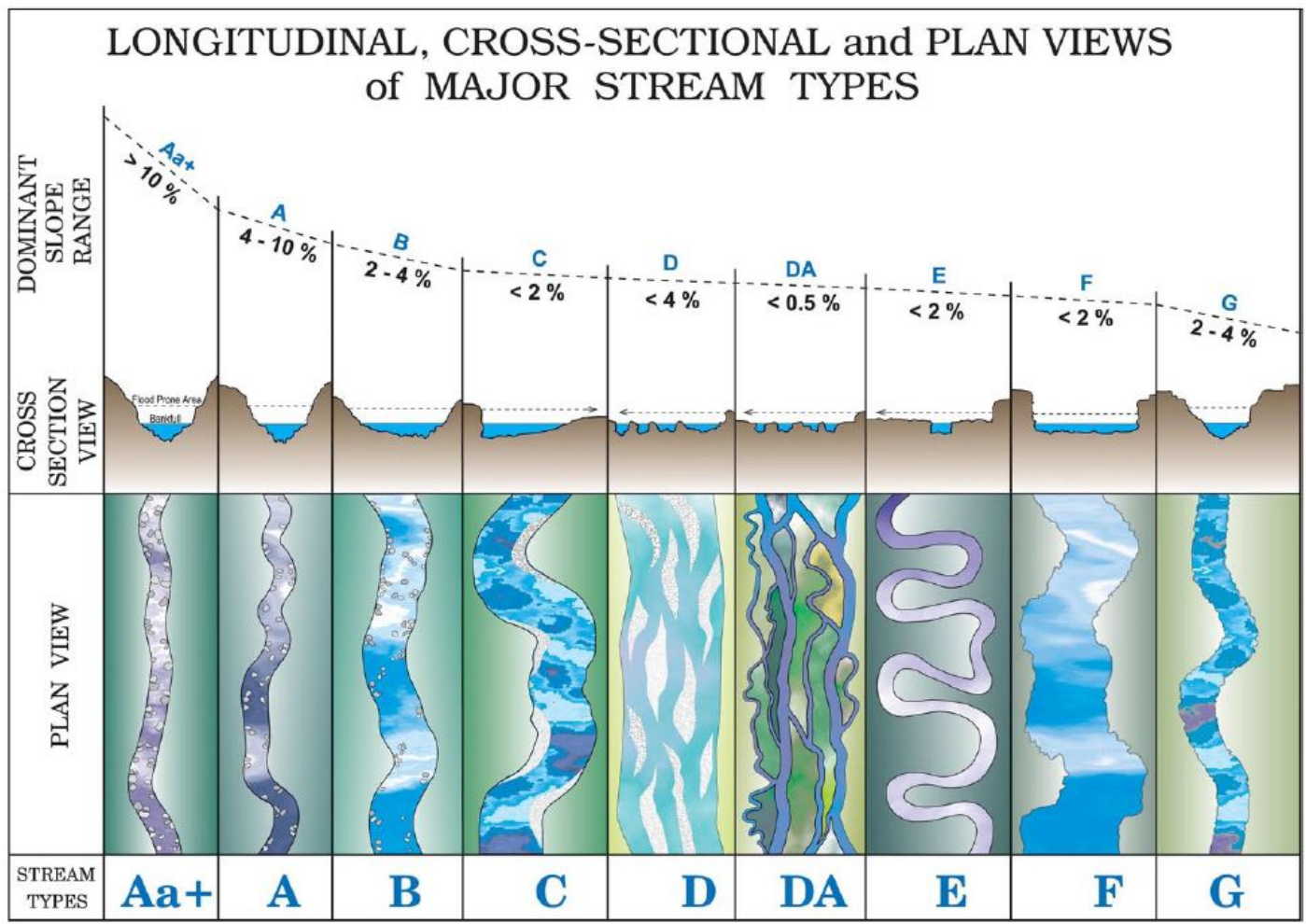

The Rosgen classification system has the advantage of using standardized measurements of morphological features, most of which are relatively easy to collect in the field. Furthermore, the system is one of the few that can potentially be applied to all stream types in all regions of the country. For the purposes of a national OHWM classification system, it is likely that only Levels I and II have potential application. Level I might work well in some locations but might be too simplistic in others. Conversely, Level II is perhaps overly detailed (i.e., there are too many categories) for the purposes of a national OHWM classification and may pose practical limitations. However, it is possible that some hybrid of the two levels might serve well to provide simplistic classification where appropriate and increased detail where necessary. One potential limitation of this classification system is the heavy reliance on bankfull parameters. While relatively simple to determine in some cases, bankfull stage is commonly difficult to 
identify, particularly in disturbed streams, heavily incised channels, arid systems, and non-perennial systems.

\subsection{Montgomery and Buffington stream channel classification}

Montgomery and Buffington (1993) developed a stream channel classification to predict watershed response to natural and anthropogenic changes. Their approach can be considered process-based, driven in part by the idea that stream channels with similar form and processes will function similarly. This classification was originally developed in the North Cascades of Washington State but was subsequently tested and expanded to include other regions of the country.

The Montgomery and Buffington stream channel classification is a hierarchical system based on processes at a variety of spatial scales: (1) geomorphic province, (2) watershed, (3) valley segment, (4) channel reach, and (5) channel unit. At the geomorphic province level, landscapes are divided into regions of similar hydrologic, erosional, and tectonic processes. This level describes how climate, geologic history, and bedrock influence the channel morphology through discharge, vegetation, and sediment supply characteristics. The next level, watershed, includes the entire area upslope from a pour point along a channel. This level includes all the processes for generating sediment and runoff into channels. Watersheds are divided into hillslopes and valleys, according to differences in sediment production and transport processes between these two landscape types. Hillslopes are areas of sediment production and may be transport or production limited while runoff and sediment transport in valleys occur through a downslope topographic convergence.

Based on the relation between sediment supply and transport capacity, the valley segment level of the classification is divided into colluvial, alluvial, and bedrock segments. Colluvial valleys are split into unchanneled and channeled valleys. Unchanneled valleys lack fluvial processes and result in an accumulation of colluvium that is excavated by mass wasting processes. Channeled colluvial valleys have channels maintained by fluvial processes, but the transport capacity is insufficient to remove all of the colluvium delivered from the surrounding hillslopes; so, the dominant sediment transport is through mass wasting. Alluvial valleys are characterized by fluvial transport of sediment over alluvial fills while, because of high sediment transport capacities, bedrock valleys lack alluvial cover. 
The channel reach level is classified based on bed morphology and roughness configurations (Table 2 ) on the premise that downstream changes to channel morphology and roughness correlate to changes in channel slope, sediment supply, and transport capacity. This separation allows for reaches to be divided into source, transport, and response reaches. Colluvial and bedrock valley segments have synonymous morphological reaches (colluvial and bedrock channels) while alluvial channels have a diversity of bed morphologies and roughness configurations. There are six alluvial channel types: braided, regime, pool-riffle, plane bed, step-pool, and cascade. Channels are distinguished from each other based on characteristics such as bed material size, channel slope, dominant roughness elements, pool spacing, bedform pattern, channel confinement, sediment supply, and transport capacity.

The last level of the classification is the channel unit, which represents morphologically similar areas within a channel reach. Common channel unit types include pools, riffles, cascades, step-pool cascades, slip-face cascades, glides, runs, and rapids; and each are defined by the areal density of clasts, local slope, flow depth, flow velocity and grain size (Montgomery and Buffington 1993). Also, at this level, habitat characteristics within a stream channel become defined.

Montgomery and Buffington's classification has potential use for developing a national OHWM classification system, particularly at the channel reach level. At this level, the emphasis is on observable morphologic features that are relevant to OHWM indicator variability and that provide for relatively rapid field classification (Table 2). The number of categories classified at this level (eight) provides a reasonable degree of detail given the practical constraints of developing a national OHWM classification. It is possible, however, that this level of classification may lack sufficient detail to adequately classify streams in some locations or circumstances. Unlike Rosgen's classification system, Montgomery and Buffington's does not further delineate stream types beyond the eight broad categories (only into channel units). Moreover, the applicability of this classification to all stream types and regions throughout the U.S. has not been fully validated. 
Table 2. Montgomery and Buffington classification categories at the channel-reach scale (after Montgomery and Buffington [1993]).

\begin{tabular}{|c|c|c|c|c|c|c|c|c|}
\hline & \multicolumn{6}{|c|}{ Alluvial } & \multirow[b]{2}{*}{ Bedrock } & \multirow[b]{2}{*}{ Colluvial } \\
\hline & Braided & Regime & Pool-Riffle & Plane Bed & Step-Pool & Cascade & & \\
\hline $\begin{array}{l}\text { Typical Bed } \\
\text { Material }\end{array}$ & Variable & Sand & Gravel & $\begin{array}{l}\text { Gravel, } \\
\text { cobble }\end{array}$ & $\begin{array}{l}\text { Cobble, } \\
\text { boulder }\end{array}$ & Boulder & N/A & Variable \\
\hline $\begin{array}{l}\text { Bedform } \\
\text { Pattern }\end{array}$ & $\begin{array}{l}\text { Laterally } \\
\text { oscillary }\end{array}$ & $\begin{array}{l}\text { Multi- } \\
\text { layered }\end{array}$ & $\begin{array}{l}\text { Laterally } \\
\text { oscillary }\end{array}$ & None & $\begin{array}{l}\text { Vertically } \\
\text { oscillary }\end{array}$ & None & - & Variable \\
\hline Reach Type & Response & Response & Response & Response & Transport & Transport & Transport & Source \\
\hline $\begin{array}{l}\text { Dominant } \\
\text { Roughness } \\
\text { Elements }\end{array}$ & $\begin{array}{l}\text { Bedforms } \\
\text { (bars, } \\
\text { pools) }\end{array}$ & $\begin{array}{l}\text { Sinuosity, } \\
\text { bedforms } \\
\text { (dunes, } \\
\text { ripples, } \\
\text { bars), } \\
\text { banks }\end{array}$ & $\begin{array}{l}\text { Bedforms } \\
\text { (bars, } \\
\text { pools), } \\
\text { grains, } \\
\text { LWD, } \\
\text { sinuosity, } \\
\text { banks }\end{array}$ & $\begin{array}{l}\text { Grains, } \\
\text { banks }\end{array}$ & $\begin{array}{l}\text { Bedforms } \\
\text { (steps, } \\
\text { pools), } \\
\text { grains, } \\
\text { LWD, } \\
\text { banks }\end{array}$ & $\begin{array}{l}\text { Grains, } \\
\text { banks }\end{array}$ & $\begin{array}{l}\text { Boundaries } \\
\text { (bed and } \\
\text { bank) }\end{array}$ & $\begin{array}{l}\text { Grains, } \\
\text { LWD }\end{array}$ \\
\hline $\begin{array}{l}\text { Dominant } \\
\text { Sediment } \\
\text { Sources }\end{array}$ & $\begin{array}{l}\text { Fluvial, } \\
\text { bank } \\
\text { failure, } \\
\text { debris } \\
\text { flow }\end{array}$ & $\begin{array}{l}\text { Fluvial, } \\
\text { bank } \\
\text { failure, } \\
\text { inactive } \\
\text { channel }\end{array}$ & $\begin{array}{l}\text { Fluvial, } \\
\text { bank } \\
\text { failure, } \\
\text { inactive } \\
\text { channel, } \\
\text { debris flow }\end{array}$ & $\begin{array}{l}\text { Fluvial, } \\
\text { bank } \\
\text { failure, } \\
\text { debris } \\
\text { flow }\end{array}$ & \begin{tabular}{|l|} 
Fluvial, \\
hillslope, \\
debris flow
\end{tabular} & $\begin{array}{l}\text { Fluvial, } \\
\text { hillslope, } \\
\text { debris flow }\end{array}$ & $\begin{array}{l}\text { Fluvial, } \\
\text { hillslope, } \\
\text { debris flow }\end{array}$ & $\begin{array}{l}\text { Hillslope, } \\
\text { debris } \\
\text { flow }\end{array}$ \\
\hline $\begin{array}{l}\text { Sediment } \\
\text { Storage } \\
\text { Elements }\end{array}$ & $\begin{array}{l}\text { Overbank, } \\
\text { bedforms }\end{array}$ & $\begin{array}{l}\text { Overbank, } \\
\text { bedforms, } \\
\text { inactive } \\
\text { channel }\end{array}$ & $\begin{array}{l}\text { Overbank, } \\
\text { bedforms, } \\
\text { inactive } \\
\text { channel }\end{array}$ & $\begin{array}{l}\text { Overbank, } \\
\text { inactive } \\
\text { channel }\end{array}$ & Bedforms & $\begin{array}{l}\text { Lee and } \\
\text { stoss sides } \\
\text { of flow } \\
\text { obstructions }\end{array}$ & - & Bed \\
\hline $\begin{array}{l}\text { Typical Slope } \\
(\mathrm{m} / \mathrm{m})\end{array}$ & $S<0.03$ & $S<0.001$ & $\begin{array}{l}0.001<S \\
\text { and } \\
S<0.02\end{array}$ & $\begin{array}{l}0.01<S \\
\text { and } \\
S<0.03\end{array}$ & $\begin{array}{l}0.03<S \\
\text { and } \\
S<0.08\end{array}$ & $\begin{array}{l}0.08<S \\
\text { and } \\
S<0.30\end{array}$ & Variable & $S>0.20$ \\
\hline $\begin{array}{l}\text { Typical } \\
\text { Confinement }\end{array}$ & $\begin{array}{l}\text { Un- } \\
\text { confined }\end{array}$ & $\begin{array}{l}\text { Un- } \\
\text { confined }\end{array}$ & $\begin{array}{l}\text { Un- } \\
\text { confined }\end{array}$ & Variable & Confined & Confined & Confined & Confined \\
\hline $\begin{array}{l}\text { Pool Spacing } \\
\text { (Channel } \\
\text { Widths) }\end{array}$ & Variable & 5 to 7 & 5 to 7 & None & 1 to 4 & $<1$ & Variable & Variable \\
\hline
\end{tabular}

* LWD = Large, woody debris

\subsection{Stream order classification}

A simple means of classifying the relative position of a given stream reach within a larger stream network was developed by Strahler (1952, 1957), who modified an earlier approach introduced by Horton (1945). Under the stream order classification system, a headwater stream with no tributaries is designated as a first-order stream. The confluence of two first-order streams marks the beginning of a second-order stream, the confluence of two second-order streams marks the beginning of a third-order stream, 
and so on throughout a stream network (e.g., Figure 7). There are many relationships between stream order and other variables such as stream size, stream density, gradient, etc. In Figure 7, for example, it is apparent that there are many more first-order streams than second order and more second-order streams than third order. In general, lower-order streams will be smaller and steeper than higher-order streams farther down in the river network. Stream order provides a geographically independent, simple, and useful way to describe a stream reach.

Figure 7. Example of the stream order classification developed by Strahler $(1952,1957)$. The numbers denote the relative position of each stream segment within the greater stream network (Wikipedia 2014).

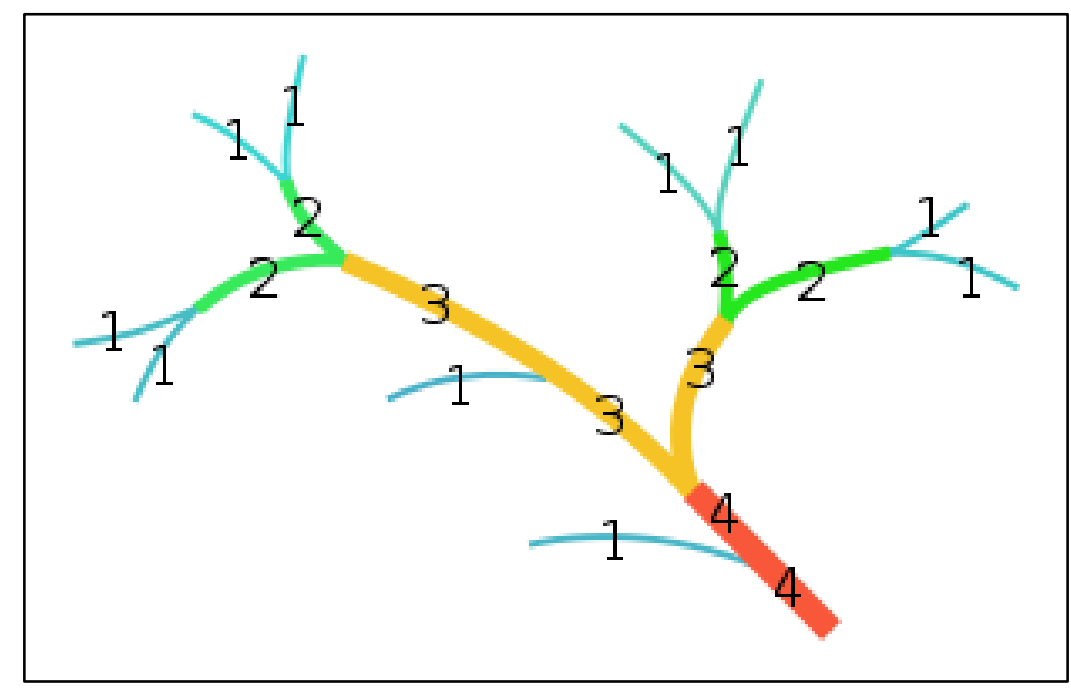

Stream order could be a useful component to include in a national OHWM classification due to the relative simplicity and objectivity with which stream order can be determined. This eliminates some of the complexity associated with other classifications that require more intensive measurement of physical variables or interpretation of stream features. Furthermore, stream order can be used as a proxy for other variables that are relevant to OHWM classification, such as stream size and slope. Stream order could be used, for instance, as the determining factor for differentiating between headwater, mid-reach, and low-gradient streams within a given region. One limitation of stream order is that it does not differentiate between different stream characteristics, such as channel pattern or substrate material, within the same order. Hence, stream order would likely need to be used in conjunction with other means of classification in order to adequately categorize streams for OHWM classification purposes. 


\subsection{Streamflow duration classification}

Streamflow duration classification methods categorize streams as perennial, intermittent, or ephemeral based on the frequency of streamflow and the degree of groundwater connection with the stream channel. Perennial streams are defined as those that flow year-round in normal years, intermittent as those that have a groundwater connection and flow during only some parts of the year, and ephemeral as those that have no connection to groundwater and flow only in response to precipitation events. Streamflow duration may play an important role in establishing and maintaining OHWM indicators. Streamflow duration classifications are typically developed at the local or regional level due to inter-regional variability in streamflow duration indicators. As such, no comprehensive, national streamflow duration assessment method currently exists. However, several local, state, and regional streamflow duration assessment methods and classifications offer potentially useful insight into the various physical and biological indicators related to streamflow duration. Below is a summary of two streamflow duration assessment methods and classifications along with discussions of their potential utility for a national OHWM classification.

\subsubsection{North Carolina Methodology for Identification of Intermittent and Perennial Streams and Their Origins}

The North Carolina Department of Water Quality (NCDWQ) developed the Methodology for Identification of Intermittent and Perennial Streams and Their Origins, Version 4.11 (NCDWQ 2010), to aid North Carolina regulatory personnel in identifying ephemeral, intermittent, and perennial streams. This methodology was developed and tested based on documented scientific principles in hydrology, geomorphology, and biology. The numerical ranking system used in this assessment method is based on results from over 300 individual field trials conducted in the piedmont and coastal plain portions of the Neuse River Basin, NC (NDCWQ 2010). This system divides a total of 25 indicators into hydrology, geomorphology, and biology indicators and rates them as absent, weak, moderate, and strong (Table 3). 
Table 3. Methodology in North Carolina for identifying intermittent and perennial streams and their origins (NCDWQ 2010).

\begin{tabular}{|c|c|c|c|c|}
\hline & Absent & Weak & Moderate & Strong \\
\hline \multicolumn{5}{|l|}{ Geomorphology } \\
\hline Continuity of channel bed and bank & 0 & 1 & 2 & 3 \\
\hline Sinuosity of channel along thalweg & 0 & 1 & 2 & 3 \\
\hline $\begin{array}{l}\text { In-channel structure: ex: riffle-pool, step- } \\
\text { pool, ripple-pool sequence }\end{array}$ & 0 & 1 & 2 & 3 \\
\hline Particle size of stream substrate & 0 & 1 & 2 & 3 \\
\hline Active/relict floodplain & 0 & 1 & 2 & 3 \\
\hline Depositional bars or benches & 0 & 1 & 2 & 3 \\
\hline Headcuts & 0 & 1 & 2 & 3 \\
\hline Grade control & 0 & 0.5 & 1 & 1.5 \\
\hline Natural valley & 0 & 0.5 & 1 & 1.5 \\
\hline Second or greater order channel & \multicolumn{2}{|l|}{ No $=0$} & \multicolumn{2}{|l|}{ Yes $=3$} \\
\hline \multicolumn{5}{|l|}{ Hydrology } \\
\hline Presence of baseflow & 0 & 1 & 2 & 3 \\
\hline Iron-oxidizing bacteria & 0 & 1 & 2 & 3 \\
\hline Leaf litter & 1.5 & 1 & 0.5 & 0 \\
\hline Sediment on plants or debris & 0 & 0.5 & 1 & 1.5 \\
\hline Organic debris lines or piles & 0 & 0.5 & 1 & 1.5 \\
\hline Soil-based evidence of high water table? & \multicolumn{2}{|l|}{ No $=0$} & \multicolumn{2}{|l|}{ Yes $=3$} \\
\hline \multicolumn{5}{|l|}{ Biology } \\
\hline Fibrous roots in streambed & 3 & 2 & 1 & 0 \\
\hline Rooted upland plants in streambed & 3 & 2 & 1 & 0 \\
\hline Macrobenthos & 0 & 1 & 2 & 3 \\
\hline Aquatic mollusks & 0 & 1 & 2 & 3 \\
\hline Fish & 0 & 0.5 & 1 & 1.5 \\
\hline Crayfish & 0 & 0.5 & 1 & 1.5 \\
\hline Amphibians & 0 & 0.5 & 1 & 1.5 \\
\hline Algae & 0 & 0.5 & 1 & 1.5 \\
\hline Wetland plants in streambed & \multicolumn{4}{|c|}{ FACW $=0.75 ;$ OBL $=1.5 ;$ Other $=0$} \\
\hline
\end{tabular}

The evaluator determines these ratings based on the average degree of development of the indicator along a stream reach of at least $100 \mathrm{ft}$ (30.48 $\mathrm{m})$. Geomorphology indicators describe channel development, hydrology 
indicators define the flow regime, and biology indicators explain if there is a continuous presence of water or not. Because of surface runoff, this methodology recommends that stream determinations not be made within 48 hours of rainfall, so scoring is made during "normal" conditions. After the evaluation of all 26 indicators, a numerical score is determined for each of the three attributes (hydrology, geomorphology, and biology); and the total score of all the attributes determines which streamflow duration category a stream reach falls into. Additionally, certain biological indicators (e.g., fish, crayfish, amphibians, or clams) indicate perennial streamflow regardless of scoring.

\subsubsection{Streamflow Duration Assessment Method for Oregon}

A second streamflow duration assessment method and classification is the Streamflow Duration Assessment Method for Oregon, developed by the EPA (Nadeau 2011). After considerable field testing and calibration, five indicators were shown to correctly determine known streamflow duration classes $78 \%$ of the time. When differentiating between ephemeral and intermittent, this method had an accuracy rate of 92\% (Nadeau 2011). The five indicators used in this approach are evaluated using a decision tree (Figure 8).

Figure 8. Streamflow Duration Assessment Method for Oregon (Nadeau 2011).

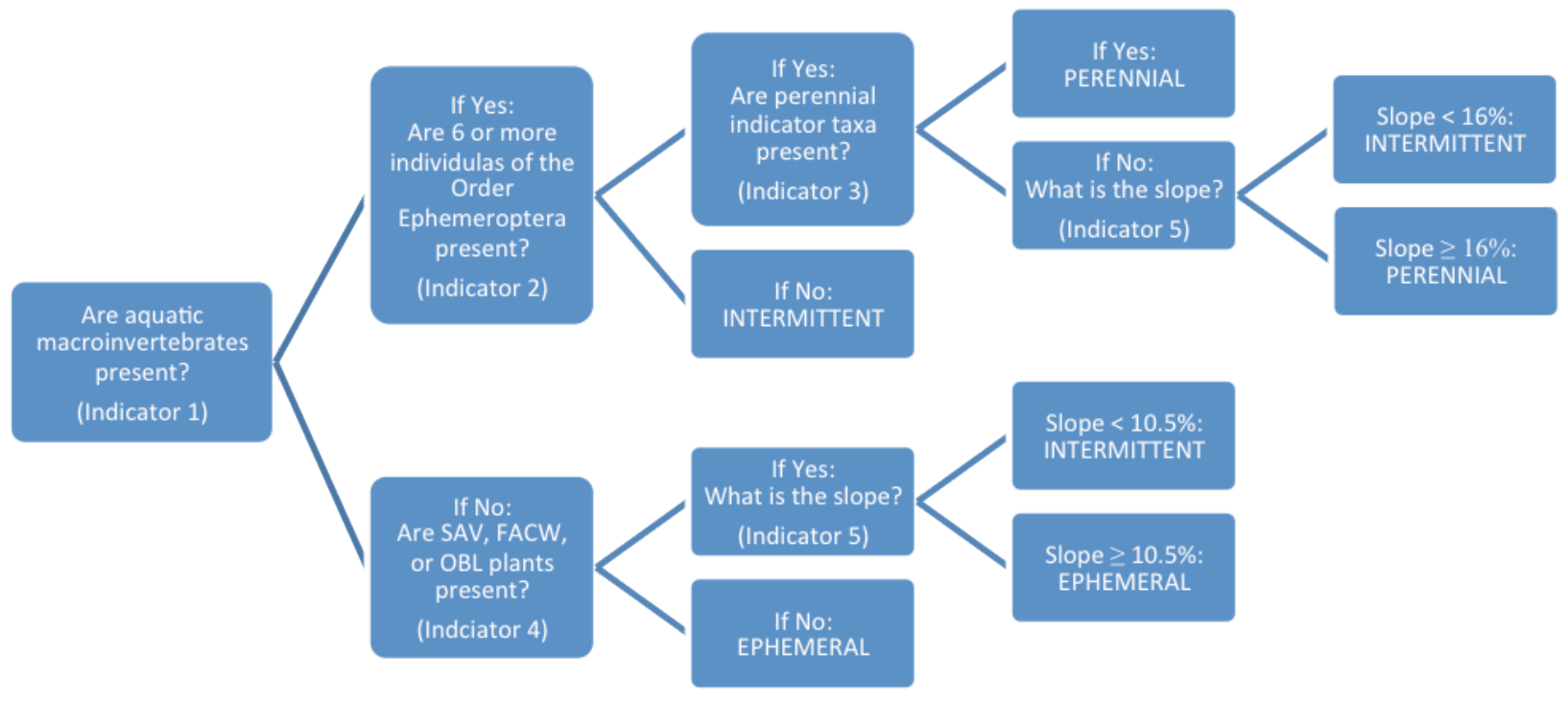

The five indicators of flow duration for the Streamflow Duration Assessment Method for Oregon include four biological indicators and only one geomorphic indicator (Figure 8). The biologic indicators relate to the presence of certain macroinvertebrates and facultative wetland and obligate 
plant species as indicated by wetland indicator status ratings on the National Wetland Plant List (Lichvar 2013). The single geomorphic indicator is based on the slope of the assessment reach. Similar to wetland delineation, this method recommends conducting this field assessment during the growing season. After the evaluation is conducted, the results of the fiveindicator field evaluation are applied to the assessment decision tree to determine the streamflow of a particular stream reach (Figure 8). There is one exception to this approach, which allows a user to determine the streamflow based solely on the presence of a fish or particular amphibian species as they are an obvious indicator of flow presence and duration (Nadeau 2011).

All streamflow duration methods are similar in that they classify streams into ephemeral, intermittent, and perennial systems. However, as with the two methods described above, the indicators used to classify streamflow duration are regionally specific. Hence, the application of a single method to determine streamflow duration nationally is unlikely. Moreover, classification of streamflow duration provides insufficient detail for a national OHWM classification, as substantial variability within a given class may exist. However, streamflow duration may play an important role in establishing and maintaining OHWM indicators and as such is an element that could potentially be included in a national OHWM classification. 


\section{Land-Water Classifications}

This section reviews several hybrid classification systems that incorporate elements of both land and stream classification. There is no clear distinction between these and some of the classifications reviewed in the previous sections; however, the three land- water classifications presented below do share some commonalities. First, in contrast to the land classifications reviewed in Section 2, these land- water classifications are geographically independent in that they are not tied to a particular geographic area. All three systems are hierarchical in structure and explicitly incorporate elements specific to stream form or habitat, such as bedforms, vegetation, climate, etc., that may influence the occurrence and distribution of OHWM indicators. Unlike the stream classifications presented in the previous section, however, the land- water classifications reviewed here do not define explicit or fixed stream categories (e.g., stream types). Instead, these classification systems define ways to categorize streams, and the landscapes in which they occur, at various spatial scales.

Although a national OHWM classification will likely require the inclusion of both explicit geographic regions and explicit stream types, a potential application of the land- water classification approaches reviewed below is to determine the scale at which OHWM indicators show significant variability or, conversely, to determine the variability in OHWM indicators at various scales. In some regions, for instance, OHWM indicators may be relatively homogenous at the watershed scale, while in others they may maintain consistency at only the reach scale. Hence, the following landwater classifications would need to be incorporated into a national OHWM classification in conjunction with a land and stream classification.

\subsection{Stream Habitat Classification}

Frissell et al. (1986) developed the Stream Habitat Classification for the purpose of assessing anthropogenic influences on stream habitats and biological communities. The framework for the classification was designed to relate to a biogeoclimate land classification system, such as that of Lotspeich and Platts (1982); and it emphasizes specific watershed variables, including biogeoclimatic region, geology, topography, soils, climate, biota, and culture. The stream habitat classification is divided into five hi- 
erarchical system levels: stream systems, segment system, reach system, pool/ riffle system, and microhabitat system (Table 4).

Table 4. Stream Habitat Classification categories (Frissell et al. 1986).

\begin{tabular}{|c|c|c|}
\hline System Level & Description & Variables \\
\hline $\begin{array}{l}\text { 1. Stream } \\
\text { Systems }\end{array}$ & All surface waters in a watershed & $\begin{array}{l}\text { Watershed class, long profile slope and } \\
\text { shape, network structure }\end{array}$ \\
\hline $\begin{array}{l}\text { 2. Segment } \\
\text { System }\end{array}$ & $\begin{array}{l}\text { Portion of a stream system flowing } \\
\text { through a single bedrock type and } \\
\text { bounded by tributary junctions or } \\
\text { major waterfalls }\end{array}$ & $\begin{array}{l}\text { Stream class, channel floor lithology, } \\
\text { channel floor slope, position in drainage } \\
\text { network, valley side slopes, potential } \\
\text { climax vegetation, soil associations }\end{array}$ \\
\hline $\begin{array}{l}\text { 3. Reach } \\
\text { System }\end{array}$ & $\begin{array}{l}\text { Length of a stream segment } \\
\text { positioned between breaks in } \\
\text { channel slope, local side slopes, } \\
\text { valley floor width, riparian } \\
\text { vegetation, and bank material }\end{array}$ & $\begin{array}{l}\text { Segment class, bedrock relief and } \\
\text { slope, morphogenetic structure or } \\
\text { process, channel pattern, local side } \\
\text { slopes and floodplain, bank } \\
\text { composition, riparian vegetation state }\end{array}$ \\
\hline $\begin{array}{l}\text { 4. Pool/Riffle } \\
\text { System }\end{array}$ & $\begin{array}{l}\text { Subsystem of a reach having } \\
\text { similar bed topography, water } \\
\text { surface slope, depth, and velocity } \\
\text { patters; pools (depositional) and } \\
\text { riffles (erosional) }\end{array}$ & $\begin{array}{l}\text { Reach class, bed topography, water } \\
\text { surface slope, morphogenetic structure } \\
\text { or process, substrates immovable in } \\
<10 \text {-year flood, bank configuration }\end{array}$ \\
\hline $\begin{array}{l}\text { 5. Microhabitat } \\
\text { System }\end{array}$ & $\begin{array}{l}\text { Areas within pool/riffle systems } \\
\text { with homogenous substrate type, } \\
\text { water depth, and velocity }\end{array}$ & $\begin{array}{l}\text { Pool/riffle class, underlying substrate, } \\
\text { overlying substrate, water depth and } \\
\text { velocity, and overhanging cover }\end{array}$ \\
\hline
\end{tabular}

The first level, stream systems, groups streams based on similar geology and climate-parameters that control network structure and longitudinal profile. Segment systems can be defined as part of a stream extending between designated tributary junctions and are units of similar slope and bedrock type. At the tributary junctions, where there is a transition between segments, differences in drainage areas and hydrologic characteristics also occur. There may be potential at this level to see differences in physical characteristics of a stream channel within different segments.

The reach system level of the Stream Habitat Classification delineates individual stream segments lying between breaks in channel slope, local side slopes, valley floor width, riparian vegetation, and bank material. A reach tends to have similar bed materials, and the length of a reach can vary greatly depending on the stream order. The reach system level is a common unit of field description used by fluvial geomorphologists. The fourth level of the Stream Habitat Classification is the pool/ riffle system. Habitat features are distinguished as pools (plunge pool, lateral scour pool, backwater pool, dammed pool), riffles, rapids, cascades, side channels, glides, and falls. At this level in the hierarchical classification system, each habitat 
type has a characteristic pattern of flow velocities, depths, sediment dynamics, water surface slope, and bed topography. The stability of these habitats depends on the morphologic features that sustain them.

The last level, microhabitat system, describes habitat patches within a pool/ riffle system that have similar substrate type, water depth, and velocity. This level of the classification is particularly important for understanding habitat and behavioral patterns for aquatic organisms and fish. To understand the habitat, it is critical to also understand the structure and arrangement of bed particles and their potential for transport. Characteristics of bed particles, such as size, shape, and transport dynamics, are highly dependent on the geology, climate, vegetation, land use, drainage position, and slope of the stream reach.

Frissell's framework for the Stream Habitat Classification provides a systematic view of spatial and temporal variation among stream systems. A unique feature of this classification is that it describes the vertical, longitudinal, and lateral boundaries of the system at all levels. A limitation is that it was designed primarily for second- and third-order perennial streams, which nominally excludes non-perennial streams and larger perennial rivers. However, the spatial relationships between classification levels for the purposes of a national OHWM classification may remain useful.

\subsection{Land-Aquatic Classification System}

The Land-Aquatic Classification System, developed by Lotspeich and Platts (1982), is a hybrid system that incorporates elements of both land and stream classification. This classification system is in part modeled after Bailey (1976) and Wertz and Arnold (1972) and is based on an ecosystem concept that integrates land classes with stream characteristics according to vegetation and geomorphic patterns. The two principal factors upon which this classification is based are climate and geology, both of which strongly influence stream characteristics. Watersheds serve as the basis for physical boundaries.

The Land-Aquatic Classification System is a hierarchical classification divided into six categories; Table 5 gives an example of each. At the coarsest level of the classification are Domains, which are based on broad climate patterns as used in Bailey's ecoregion classification. The second category, Province, partitions Domains into smaller units based on large-scale landforms where drainage patterns can start to be identified. Provinces are fur- 
ther divided into Sections, which are comparable to the lowest level in Bailey's ecoregion classification and are based on macroclimates and geologic features where similar weathering processes become apparent. Sections are then divided into Regions, in which vegetation and drainage patterns become apparent due to the variable influence of topography, elevation, and lithology. In the fifth category, Land-Type Association, first-order streams are identified. Finally, in the sixth and last category, Land Type, small-scale stream habitats are identified (Lotspeich and Platts 1982).

Table 5. Land-Aquatic Classification System categories.

\begin{tabular}{|l|l|l|}
\hline \multicolumn{1}{|c|}{ Division } & \multicolumn{1}{|c|}{ Description } & \multicolumn{1}{c|}{ Example } \\
\hline Domain & $\begin{array}{l}\text { Climatic separation based on Bailey } \\
(1976)\end{array}$ & Arid and humid climates \\
\hline Province & $\begin{array}{l}\text { Large physiographic units with } \\
\text { homogeneous geology }\end{array}$ & $\begin{array}{l}\text { Fault block (interior stream } \\
\text { drainage), folded mountains (parallel } \\
\text { stream patterns), coastal plain (low- } \\
\text { gradient streams) }\end{array}$ \\
\hline Section & $\begin{array}{l}\text { Land units based on uniform } \\
\text { macroclimate and geology (including } \\
\text { lithology) }\end{array}$ & $\begin{array}{l}\text { Basalt cap-semiarid, sedimentary- } \\
\text { arid, and quartzite-subhumid }\end{array}$ \\
\hline Region & $\begin{array}{l}\text { Lithology and structure determined } \\
\text { by drainage patterns; vegetation } \\
\text { patterns also apparent in relation to } \\
\text { topography and elevation }\end{array}$ & $\begin{array}{l}\text { Dendritic stream structure, trellis } \\
\text { stream structure, radial-annual } \\
\text { stream structure }\end{array}$ \\
\hline $\begin{array}{l}\text { Land-Type } \\
\text { Association }\end{array}$ & $\begin{array}{l}\text { First-order watersheds and } \\
\text { characteristics of stream habitats } \\
\text { and vegetation patterns }\end{array}$ & $\begin{array}{l}\text { Separation between tesserae and } \\
\text { aquatic communities; first-order } \\
\text { streams now identified }\end{array}$ \\
\hline Land Type & $\begin{array}{l}\text { Stream habitats based on } \\
\text { geomorphic properties }\end{array}$ & Homogenous aquatic habitats \\
\hline
\end{tabular}

A unique benefit of the Land-Aquatic Classification System is that the higher-level classes overlap to a large degree with those of Bailey's ecoregion classification. At finer scales, the Land-Aquatic Classification System provides increasing detail pertaining specifically to stream features that is not found in Bailey's classification system. Thus, this approach may be particularly useful for a national OHWM classification if used in conjunction with Bailey's ecoregion classification.

\subsection{River Environment Classification}

The River Environment Classification (REC) was developed by Snelder and Biggs (2002) as a hierarchical approach to classifying and mapping spatial patterns in river ecosystems. This classification is based on four factors - climate, topography, geology, and land cover - the major factors 
thought to control physical patterns within a river environment. Climate and topography control flood flow regimes, erosion, and sediment transport processes while land cover and geology control processes within the channel (Snelder and Biggs 2002). This approach uses geographic information system (GIS) capabilities to incorporate multiple datasets in order to map river networks based on the specified criteria. The REC is divided into six main system levels: climate, source of flow, geology, land cover, network position, and valley landform. Each level represents a set of processes that are expressed through patterns in physical and biotic components of rivers at a particular spatial scale. The first four levels (climate, source of flow, geology, and land cover) characterize watershed processes that supply and route water, sediment, and other constituents of flow through and off a landscape while the last two (network position and valley landform) characterize local processes that are thought to result from watershed processes interacting with topographic factors at the local channel network scale (Montgomery 1999, cited in Snelder and Biggs 2002). Table 6 gives a description of each of the six controlling factors and categories of the classification.

A major benefit of the REC is that it was explicitly designed to be implemented in a GIS framework. This allows for relatively rapid classification of a large geographic region at various scales by using available datasets. This approach was used to map the entire country of New Zealand with much success (Snelder and Biggs 2002). The REC could likewise be used to map the entire U.S. at various scales, potentially identifying unique stream regions. Moreover, this classification heavily emphasizes channel form and physical characteristics of stream systems, which are likely to be more relevant to OHWM indicator patterns than habitat characteristics. 
Table 6. River Environment Classification categories (after Snelder and Biggs [2002]).

\begin{tabular}{|c|c|c|}
\hline $\begin{array}{l}\text { Controlling } \\
\text { Factors }\end{array}$ & Description & Categories \\
\hline \multirow[t]{6}{*}{ 1. Climate } & \multirow{6}{*}{$\begin{array}{l}\text { Describes the climatic processes that drive the } \\
\text { hydrological cycle and water temperature regimes } \\
\text { (i.e., precipitation, evapotranspiration, } \\
\text { temperature) }\end{array}$} & Warm Extremely Wet \\
\hline & & Warm Wet \\
\hline & & Warm Dry \\
\hline & & Cool Extremely Wet \\
\hline & & Cool Wet \\
\hline & & Cool Dry \\
\hline \multirow{4}{*}{$\begin{array}{l}\text { 2. Source of } \\
\text { flow }\end{array}$} & \multirow{4}{*}{$\begin{array}{l}\text { Describes watershed processes of hydrology, } \\
\text { sediment supply, and transport processes based } \\
\text { on watershed topography }\end{array}$} & Mountain \\
\hline & & Hill \\
\hline & & Low Elevation \\
\hline & & Lake \\
\hline \multirow[t]{6}{*}{ 3. Geology } & \multirow{6}{*}{$\begin{array}{l}\text { Influences erosion rates, substrate, and } \\
\text { sediment particle size. Controls variation in } \\
\text { hydrology, sediment supply, hydrochemcial } \\
\text { processes, groundwater storage capacity and } \\
\text { transmissivity }\end{array}$} & Alluvium \\
\hline & & Hard Sedimentary \\
\hline & & Soft Sedimentary \\
\hline & & Volcanic Basic \\
\hline & & Volcanic Acidic \\
\hline & & Plutonic \\
\hline \multirow[t]{8}{*}{ 4. Land cover } & \multirow{8}{*}{$\begin{array}{l}\text { Describes different vegetation types that } \\
\text { influence surface interception of rainfall, } \\
\text { evapotranspiration, erosion rates, and sediment } \\
\text { supply }\end{array}$} & Bare \\
\hline & & Indigenous Forest \\
\hline & & Pasture \\
\hline & & Tussock \\
\hline & & Scrub \\
\hline & & Exotic Forest \\
\hline & & Wetland \\
\hline & & Urban \\
\hline \multirow{3}{*}{$\begin{array}{l}\text { 5. Network } \\
\text { position }\end{array}$} & \multirow{3}{*}{$\begin{array}{l}\text { Describes flux of water, sediment, and other } \\
\text { characteristics of the flow that change along the } \\
\text { network position }\end{array}$} & Low Order \\
\hline & & Middle Order \\
\hline & & High Order \\
\hline \multirow{3}{*}{$\begin{array}{l}\text { 6. Valley } \\
\text { landform }\end{array}$} & \multirow{3}{*}{$\begin{array}{l}\text { Valley shape and geological features; influences } \\
\text { local sediment transport, channel erosion, and } \\
\text { sediment deposition }\end{array}$} & High Gradient \\
\hline & & Medium Gradient \\
\hline & & Low Gradient \\
\hline
\end{tabular}




\section{Summary and Discussion}

The various land and stream classifications described in the previous sections represent but a small subset of existing classification approaches. Each classification was designed for a specific purpose, resulting in unique class boundaries based on unique factors. The challenge is to identify which aspects of these various classifications best suit the needs of a national OHWM classification approach and to balance the level of classification detail with the logistical limitations of sampling each class (i.e., each category or classification unit) at the national scale. No single existing classification has been identified that meets all of the criteria for a national OHWM classification. Hence, a reasonable solution is to combine various elements of existing land and stream classifications to design a unique approach that meets the particular requirements of a national OHWM classification. The following sections summarize and discuss in broad terms the benefits and limitations of the reviewed classifications.

\subsection{Land classifications}

To account for regional variability in stream characteristics and to allow for regionally focused OHWM investigations and guidance, it is desirable to include a geographic component in a national OHWM classification. Geographic divisions and regions should be related to the spatial distribution of different stream types, but they should not be overly detailed such that sampling each region is impractical for logistical reasons.

The LRR/ MLRA (USDA 2006), Bailey's ecoregion (Bailey 1976, 1980, 1983), and Omernik's ecoregion (Omernik 1987, Omernik and Bailey 1997) classifications are each based on a collection of environmental variables, only some of which are directly related to spatial patterns in stream characteristics. The geographic divisions in each of these classifications are generally overly detailed (or too coarse in the case of Bailey's domain division and Omernik's Level I division) for the purpose of a national OHWM classification and would need to be regrouped into a more suitable number of regions. The above limitations aside, these three land classifications have the advantage of being widely used by and familiar to a broad audience. These geographic divisions likely have some relationship to the distribution of stream characteristics and thus OHWM characteristics; and furthermore, the hierarchical approach used in each of these three classifi- 
cations allows for the potential of downscaling broad geographic regions into finer-scaled regions (or sub-regions) if deemed necessary for a particular location or stream type.

Of the five land classifications reviewed, the Channel Form and Stream Ecosystem Model (Brussock et al. 1985) is the only one designed specifically to identify broad spatial patterns in stream characteristics within the U.S. Moreover, it provides a level of classification detail that is suitable to the purposes of a national OHWM classification (i.e., the regions are neither too coarse nor too fine). However, this classification delineates regions at only one spatial scale and does not provide for downscaling. Another limitation of this classification is that it incorporates only the contiguous U.S., so additional regions would need to be identified for the remaining U.S. states and territories.

The Corps wetland regions (Berkowitz 2011) incorporate all of the U.S., including Alaska, Hawaii, and the Caribbean territories, and also provide a suitable level of classification detail (10 regions). Although these regions were designed to reflect broad-scale variability in wetland characteristics, stream characteristics are controlled by many of the same factors (climate, geology, topography, etc.). Indeed, the Corps wetland regions (Figure 2) have similar boundaries to the stream regions identified in the Channel Form and Stream Ecosystem Model (Figure 5). Moreover, existing OHWM delineation guidance for the Arid West Region (Lichvar and McColley 2008) and the Western Mountains, Valleys, and Coast Region (Mersel and Lichvar 2014) is organized along similar geographic lines as the Corps wetland regions. Adoption of the Corps wetland regions for national OHWM classification purposes would allow for geographic continuity in the regionalization of wetland and stream delineation technical guidance. Lastly, because the Corps wetland regions are aggregated from USDA LRRs and MLRAs, they can be partitioned into smaller geographic units (subregions) if deemed necessary in a particular region. For all of these reasons, the Corps wetland regions are the most suitable geographic component to include in a national OHWM classification.

\subsection{Stream classifications}

In addition to a geographical component, a national OHWM classification should also include a component to differentiate between stream types or characteristics within each region. This component should account for the major differentiating factors between stream types; but as with the geo- 
graphic component, it should not be overly detailed such that sampling each stream class within each region is logistically impractical.

Although countless stream classifications have been developed over time, most are specific to a particular region or designed for a specific purpose that is not directly relevant to a national OHWM classification. Few have been designed to encompass the full range of stream variability that exists throughout the U.S. The four approaches to stream classification reviewed in Section 3 are a subset that can be applied at the national scale (note that classification of streamflow duration can be applied nationally but that the existing methods for doing so are regionally focused) and that are relevant to a national OHWM classification. They represent substantially different approaches to stream classification, and each has unique benefits and limitations.

Streamflow duration is a potentially important factor related to the formation and maintenance of OHWM indicators. It is relatively simple in concept, and the classification of streamflow duration can be applied universally to any stream in any location. However, the spatial and temporal dynamics of streamflow duration make its determination in the field challenging; and existing methods for determining streamflow duration are regionally focused (e.g., NCDWQ 2010; Nadeau 2011) and are not readily available for each region of the U.S. Moreover, classification of streamflow duration does not account for variability in channel form; and conversely, classifications that do account for channel form (e.g., those by Montgomery and Buffington [1993] or Rosgen [1994]) do not explicitly account for streamflow duration.

Stream order (Strahler 1952, 1957) is a convenient means of classifying streams because it is simple in both concept and implementation, and the various classes are relative to a given region (e.g., first-order streams exist in every region but may have substantially different characteristics in each region). Furthermore, stream order is a proxy for many other stream characteristics (slope, size, etc.) that are potentially relevant to OHWM indicator patterns. However, a limitation of stream order is that it does not explicitly account for differences in stream form, process, or function; and streams of a given order may encompass a wide range of variability in these characteristics. 
The two stream classifications that overcome most of these limitations are those of Montgomery and Buffington (1993) and Rosgen (1994). Both are comprehensive and account for much of the broad-scale variability in stream systems throughout the U.S. Montgomery and Buffington incorporate elements of stream processes into their classification while Rosgen's is based purely on channel form. Of the two, however, the Rosgen Classification of Natural Rivers has several additional benefits. The Rosgen classification is familiar to a wide audience and has already been adopted by a number of state and federal agencies for a variety of purposes. But perhaps more importantly, the Rosgen classification is based on quantitative measurements that may reduce user subjectivity in classifying a particular stream. Additionally, the Rosgen classification allows for increasingly detailed partitioning of stream types beyond the broad classes, which may be necessary in some regions if this scale is insufficient. For these reasons, the Rosgen Classification of Natural Rivers is the most suitable stream component to include in a national OHWM classification.

\subsection{Land-water classifications}

The Stream Habitat Classification (Frissell et al. 1986), the Land- Aquatic Classification System (Lotspeich and Platts 1982), and the River Environment Classification (Snelder and Biggs 2002) are hybrid classification systems that incorporate elements of both land and stream classifications. These classifications are geographically independent and do not define explicit or fixed geographic regions or stream types. Rather, these classifications were designed to, at various scales, classify a given stream and the landscape in which it occurs. As such, these approaches could be used in conjunction with a land or stream classification to assess OHWM indicator patterns at various scales. One possibility is to use one of these approaches to identify the scale at which OHWM indicators vary within a given region, watershed, or stream system. Substantial processing would be required to define broad stream regions within the U.S. by using any of these classification approaches.

Of the three land- water classifications reviewed, the REC places the greatest emphasis on physical characteristics of streams and watersheds (e.g., stream order and gradient). These characteristics are more likely to have relationships with OHWM indicator patterns than are the habitat features emphasized in the Stream Habitat Classification and the Land- Aquatic Classification System. Moreover, the implementation of the REC in a GIS framework allows for relatively rapid classification at a variety of scales. 
For these reasons, the REC is likely the most suitable land- water classification for national OHWM classification purposes. 


\section{Proposed National OHWM Classification}

After considering the benefits and limitations of a variety of existing land, stream, and hybrid classification approaches, this section outlines a preliminary version of a national OHWM classification and gives recommendations for its implementation. This version is subject to revision, improvement, and further refinement; but at a minimum it will highlight a general classification approach to be used in future OHWM investigations.

The proposed structure of the national OHWM classification overlays the Rosgen Level I stream classification categories on top of the Corps wetland regions. This effectively denotes nine potential stream types within each of the 10 regions. Table 7 gives the Northcentral and Northeast region as an example where seven of the nine potential stream types are indicated to be fairly well represented throughout the region.

Table 7. Example of the proposed national OHWM classification in the Northcentral and Northeast region. In this table, the Rosgen Level I stream categories are overlain on the Northcentral and Northeast Corps Wetland Region. The check marks indicate which of the nine potential stream types are reasonably well represented in the region. The same approach can be applied to each of the 10 Corps wetland regions to help determine which stream types to sample.

\begin{tabular}{|l|c|c|c|c|c|c|c|c|c|}
\hline Corps Wetland Region & Aa+ & A & B & C & D & DA & E & F & G \\
\hline Northcentral and Northeast & $\checkmark$ & $\checkmark$ & $\checkmark$ & $\checkmark$ & & & $\checkmark$ & $\checkmark$ & $\checkmark$ \\
\hline
\end{tabular}

In implementing this classification system, one should first attempt to identify which of the nine stream types are well represented within a given region (e.g., Table 7). Some stream types are particular to certain regions. Braided streams (Rosgen type D), for instance, are typically found in glacial settings, such as the northwestern U.S. and Alaska, and in dryland systems, such as are found throughout much the western U.S. Conversely, very steep streams (Rosgen type $\mathrm{Aa}+$ ) are not found in relatively flat locations, including much of the mid-western and southeastern U.S. Sample sites should be chosen so as to include all of the stream types that are fairly well represented within that region. Level I stream types can be parsed into more specific categories using the Level II classification if deemed necessary for a particular stream type or region. Likewise, the 10 Corps wetland regions can be parsed into more detailed stream regions using $L R R$ and MLRA geographic boundaries if deemed necessary. 
An optional addition to the proposed national OHWM classification is to use the REC to classify selected study sites at a range of scales. That is, once sample sites have been chosen to reflect the diversity of stream types within a given region, these sites could be further classified using the REC. Subsequent analysis could then attempt to determine the scale at which OHWM indicators become notably variable. Implementation of this option would depend on the range of OHWM indicator variability detected within a region and whether or not OHWM indicator variability is sufficiently explained by differences in stream type or some other factor.

An important factor missing from the national OHWM classification approach outlined above is that of streamflow duration. The frequency of streamflow in a channel may have a substantial influence on the occurrence and appearance of various physical and biological OHWM indicators. However, the relationship between streamflow duration and other factors, such as channel form and processes, varies substantially between different regions. Ephemeral streams in the Arid West, for instance, dominate much of the landscape and can take on a variety of channel forms. In more humid climates, however, there tends to be a much stronger relationship between channel slope, channel size, and streamflow duration (e.g., ephemeral streams tend to be relatively small and steep). Given the compounding complexity that streamflow duration introduces to stream classification, it is suggested that this factor be dealt with on a region-byregion basis. In regions where ephemeral and intermittent streams are more prominent and diverse (in terms of channel form or process), they can be sampled more heavily across a range of channel types. Conversely, where ephemeral streams are less prominent and are primarily associated with a limited set of channel forms, the sampling strategy can be adjusted accordingly.

An additional factor not included in this classification, but that will likely need to be addressed in the development of OHWM delineation technical guidance, is the influence of anthropogenic impacts (e.g., land use, hydromodification, etc.) on stream channel, and thus OHWM, characteristics. These impacts will potentially be addressed as "problematic" stream types or circumstances that are not explicitly included in the OHWM classification.

The aim of this proposed classification is to provide a standardized framework for investigating the OHWM and its indicators in different stream 
types and regions. This is not to suggest, however, that subsequent technical guidance will necessarily be organized in the same manner or along the same lines. That is, OHWM delineation guidance may be organized by regions or stream types that are different from those used in the proposed classification. In light of future field investigations, it may be concluded, for instance, that the OHWM shows no notable distinctions between two different regions and that those two regions may be grouped into one for the purposes of developing OHWM delineation technical guidance. Likewise, it may be concluded that multiple stream types within a given region exhibit no distinctions with regard to OHWM indicators and that those stream types may be grouped into one. OHWM delineation technical guidance could ultimately be organized by region, by stream type, or by some combination of both. 


\section{References}

Bailey, R. G. 1976. Ecoregions of the United States (map). Ogden, UT: U.S. Department of Agriculture, U.S. Forest Service.

Bailey, R. G. 1980. Description of the Ecoregions of the United States. Miscellaneous Publication 1391. Washington, DC: U.S. Department of Agriculture, U.S. Forest Service.

Bailey, R. G. 1983. Delineation of ecosystem regions. Environmental Management 7 (4): 365- 373.

Bailey, R. G. 1995. Description of the Ecoregions of the United States. Fort Collins, CO: U.S. Forest Service, Rocky Mountain Research Station. http://www.fs.fed.us/land/ecosysmgmt/.

Berkowitz, J . F. 2011. Updating regional supplements to the Corps of Engineers Wetland Delineation Manual. WRAP Technical Notes Collection. ERDC TN-WRAP-12-1. Vicksburg, MS: U.S. Army Engineer Research and Development Center.

Brussock, P. P., A. V. Brown, and J . C. Dixon. 1985. Channel form and stream ecosystem models. J ournal of the American Water Resources Association 21 (5): 859- 866. doi:10.1111/j.1752-1688.1985.tb00180.x.

Buffington, J . M., and D. R. Montgomery. 2013. 9.36 Geomorphic Classification of Rivers. In Treatise on Geomorphology, ed. J. F. Shroder, 730- 767. San Diego, CA: Academic Press. http://linkinghub.elsevier.com/retrieve/pii/B9780123747396002633.

Cowardin, L. M., V. Carter V., F. C. Golet, and E. T. LaRoe. 1979. Classification of Wetlands and Deepwater Habitats of the United States. FWS/OBS/-79/31. Washington, DC: U.S. Fish and Wildlife Service.

Curtis, K. E., R. W. Lichvar, and L. Dixon. 2011. Ordinary High Flows and the StageDischarge Relationship in the Arid West Region. ERDC/CRREL TR-11-12. Hanover, NH: U.S. Army Engineer Research and Development Center.

Davis, W. M. 1899. The Geographical Cycle. The Geographical J ournal 14 (5): 481- 504. doi:10.2307/ 1774538.

Environmental Laboratory. 1987. Corps of Engineers Wetlands Delineation Manual. Technical Report Y-87-1. Vicksburg, MS: U.S. Army Environmental Laboratory.

Frissell, C. A., W. J . Liss, C. E. Warren, and M. D. Hurley. 1986. A hierarchical framework for stream habitat classification: Viewing streams in a watershed context. Environmental Management 10: 199- 214.

Graf, W. L. 1988. Fluvial Processes in Dryland Rivers. Caldwell, NJ : The Blackburn Press. 
Horton, R. E. 1945. Erosional development of streams and their drainage basins: Hydrophysical approach to quantitative morphology. Geological Society of America Bulletin 56 (3): 275- 370. doi:10.1130/ 0016-7606(1945)56[275: EDOSAT]2.0.CO;2.

Lefebvre, L., R. Lichvar, and K. Curtis. 2013a. Survey of OHWM Indicator Distribution Patterns Across Arid West Landscapes. ERDC/ CRREL TR-13-2. Hanover, NH: U.S. Army Engineer Research and Development Center.

Lefebvre, L., R. Lichvar, K. Curtis, and J . Gillrich. 2013b. Channel Classification Across Arid West Landscapes in Support of OHW Delineation. ERDC/CRREL TR-13-3. Hanover, NH: U.S. Army Engineer Research and Development Center.

Leopold, L. B., and M. G. Wolman. 1957. River Channel Patterns: Braided, Meandering, and Straight. Professional Paper 282-B. Reston, VA: U.S. Geological Survey.

Lichvar, R. W. 2013. The National Wetland Plant List: 2013 Wetland Ratings. Phytoneuron 49:1- 241.

Lichvar, R. W., and S. M. McColley. 2008. A Field Guide to the Identification of the Ordinary High Water Mark (OHWM) in the Arid West Region of the Western United States. ERDC/ CRREL TR 06-5. Hanover, NH: U.S. Army Engineer Research and Development Center.

Lichvar, R. W., and J. S. Wakeley. 2004. Review of Ordinary High Water Mark Indicators for Delineating Arid Streams in the Southwestern United States. ERDC TR-04-1. Hanover, NH: U.S. Army Engineer Research and Development Center.

Lichvar, R. W., D. C. Finnegan, M. P. Ericsson, and W. Ochs. 2006. Distribution of Ordinary High Water Mark (OHWM) Indicators and Their Reliability in Identifying the Limits of "Waters of the United States" in Arid Southwestern Channels. ERDC/CRREL TR-06-5. Hanover, NH: U.S. Army Engineer Research and Development Center.

Lichvar, R. W., D. Cate, C. Photos, L. Dixon, B. Allen, and J . Byersdorfer. 2009. Vegetation and Channel Morphology Responses to Ordinary High Water Mark Discharge Events in Arid West Stream Channels. ERDC/ CRREL TR-09-5. Hanover, NH: U.S. Army Engineer Research and Development Center.

Lotspeich, F. B., and W. S. Platts. 1982. An Integrated Land-Aquatic Classification System. North American J ournal of Fisheries Management 2 (2): 138- 149.

Mersel, M. K., and R. W. Lichvar. 2014. A Guide to Ordinary High Water Mark (OHWM) Delineation for Non-Perennial Streams in the Western Mountains, Valleys, and Coast Region of the United States. ERDC/ CRREL TR. Hanover, NH: U.S. Army Engineer Research and Development Center.

Mersel, M. K., R. W. Lichvar, J . J. Gillrich, and L. E. Lefebvre. 2014. Occurrence and Distribution of Ordinary High Water Mark (OHWM) Indicators in NonPerennial Streams in the Western Mountains, Valleys, and Coast Region of the United States. ERDC/CRREL TR. Hanover, NH: U.S. Army Engineer Research and Development Center. 
Montgomery, D. R. 1999. Process domains and the river continuum. J ournal of the American Water Resources Association 35 (2): 397- 410.

Montgomery, D. R., and J . M. Buffington. 1993. Channel Classification, Prediction of Channel Response, and Assessment of Channel Condition. Report TFW-SH1093-002. Olympia, WA: Washington State Department of Natural Resources.

Nadeau, T-L. 2011. Streamflow Duration Assessment Method for Oregon. EPA 910-R-11002. Portland, OR: U.S. Environmental Protection Agency, Region 10.

North Carolina Division of Water Quality (NCDWQ). 2010. Methodology for Identification of Intermittent and Perennial Streams and their Origins, Version 4.11. Raleigh, NC: North Carolina Department of Environment and Natural Resources, Division of Water Quality.

Omernik, J. M. 1987. Ecoregions of the conterminous United States. Annals of the Association of American Geographers 77:118- 125.

Omernik, J. M., and R. G. Bailey. 1997. Distinguishing between watersheds and ecoregions. J ournal of the American Water Resources Association 33 (5): 935949.

Rosgen, D. 1994. A classification of natural rivers. Catena 22: 169- 199.

Rosgen, D. 1996. Applied River Morphology. Pagosa Springs, CO: Wildland Hydrology.

Snelder, T. H., and B. J . F. Biggs. 2002. Multiscale river environment classification for water resources management. American Water Resources Association Bulletin 38 (5): 1225- 1239.

Strahler, A. N. 1952. Hypsometric (area-altitude) analysis of erosional topography. Geological Society of America Bulletin 63 (11): 1117- 1142. doi:10.1130/00167606(1952)63[1117:HAAOET]2.0.CO;2.

Strahler, A. N. 1957. Quantitative analysis of watershed geomorphology. Transactions of the American Geophysical Union 38 (6): 913- 920.

U.S. Congress. 1977. Clean Water Act. Codified at 33 U.S.C. 1251 (et seq.). Washington, DC: U.S. Government Printing Office.

U.S. Congress. 1986. Definition of "Waters of the United States." Codified at 33 CFR 328.3 (et seq.). Washington, DC: U.S. Government Printing Office.

U.S. Department of Agriculture (USDA). 1998. Land Resource Regions (LRR). Map ID: 3966. Washington, DC: U.S. Department of Agriculture, Natural Resources Conservation Service. http://www.nrcs.usda.gov/wps/portal/nrcs/detail//?cid= nrcs143_013721.

U.S. Department of Agriculture (USDA). 2006. Land Resource Regions and Major Land Resource Areas of the United States, the Caribbean, and the Pacific Basin. Agriculture Handbook 296. Washington, DC: U.S. Department of Agriculture, Natural Resources Conservation Service. 
U.S. Environmental Protection Agency (EPA). 2006. Ecological Regions of North America. Washington, DC: U.S. Environmental Protection Agency. http://www.epa.gov/wed/pages/ecoregions/na_eco.htm.

U.S. Environmental Protection Agency (EPA). 2008. Longitudinal, Cross-sectional and Plan Views of Major Stream Types. Washington, DC: U.S. Environmental Protection Agency. http://water.epa.gov/scitech/datait/tools/warsss/upload/ 2008_08_25_watershed_tools_warsss_sedsource_fig14.pdf.

Wakeley, J . S. 2002. Developing a "Regionalized" Version of the Corps of Engineers Wetlands Delineation Manual: Issues and Recommendations. ERDC/ EL TR-0220. Vicksburg, MS: U.S. Army Engineer Research and Development Center.

Wertz, W. A., and J . F. Arnold. 1972. Land Systems Inventory. Ogden, UT: U.S. Department of Agriculture, U.S. Forest Service, Intermountain Region.

Wikipedia. 2014. Strahler number. Wikipedia. http://en.wikipedia.org/wiki/Strahler_number. 


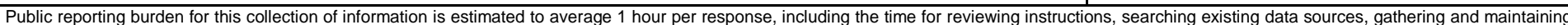

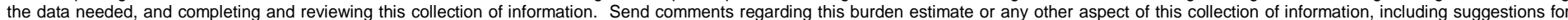

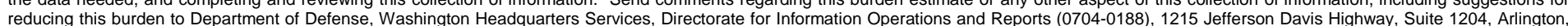

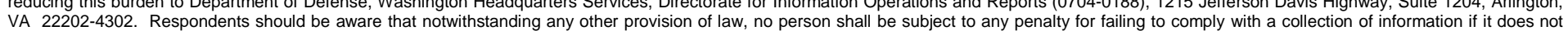
VA 22202-4302. Respondents should be aware that notwithstanding any other provision of law, no person shall be subs
display a currently valid OMB control number. PLEASE DO NOT RETURN YOUR FORM TO THE ABOVE ADDRESS.

\begin{tabular}{l|l}
$\begin{array}{l}\text { 1. REPORT DATE (DD-MM-YYYY) } \\
\text { August } 2014\end{array}$ & $\begin{array}{l}\text { 2. REPORT TYPE } \\
\text { Technical Report/ Final }\end{array}$ \\
\hline
\end{tabular}

\section{TITLE AND SUBTITLE}

A Review of Land and Stream Classifications in Support of Developing a National Ordinary High Water Mark (OHWM) Classification

3. DATES COVERED (From - To)

5a. CONTRACT NUMBER

5b. GRANT NUMBER

5c. PROGRAM ELEMENT NUMBER

\section{AUTHOR(S)}

\section{5d. PROJECT NUMBER}

Matthew K. Mersel, Lindsey E. Lefebvre, and Robert W. Lichvar

5e. TASK NUMBER

5f. WORK UNIT NUMBER

7. PERFORMING ORGANIZATION NAME(S) AND ADDRESS(ES)

8. PERFORMING ORGANIZATION REPORT
NUMBER

U.S. Army Engineer Research and Development Center

Cold Regions Research and Engineering Laboratory

ERDC/CRREL TR-14-12

72 Lyme Road

Hanover, NH 03755-1290

9. SPONSORING I MONITORING AGENCY NAME(S) AND ADDRESS(ES)

10. SPONSOR/MONITOR'S ACRONYM(S)

Wetlands Regulatory Assistance Program (WRAP)

U.S. Army Corps of Engineers

Vicksburg, MS 39180-6133

11. SPONSOR/MONITOR'S REPORT NUMBER(S)

\section{DISTRIBUTION / AVAILABILITY STATEMENT}

Approved for public release; distribution is unlimited.

\section{SUPPLEMENTARY NOTES}

\section{ABSTRACT}

Under Section 404 of the Clean Water Act, the ordinary high water mark (OHWM) defines the lateral extent of federal jurisdiction in non-tidal waters of the United States in the absence of adjacent wetlands. Extensive research pertaining to identification and delineation of the OHWM in rivers and streams of the Arid West and Western Mountains, Valleys, and Coast regions has been conducted to better understand the occurrence and distribution of OHWM field indicators and to develop reliable methods for delineating the OHWM in these regions. Ongoing expansion of OHWM investigations into other regions of the U.S. stems from a need for nationally consistent and defensible OHWM delineation practices. A comprehensive framework is needed to foster the expansion of OHWM research and the development of delineation methods and indicators. A key element of this framework is the implementation of a classification system that allows for systematic sampling of the range of stream types and regions that exist throughout the U.S. This report reviews existing land and stream classifications and assesses the benefits and limitations of each approach for the purpose of developing a national OHWM classification. Additionally, it presents a preliminary version of a national OHWM classification.

\section{SUBJECT TERMS}

Classification

Land classification

16. SECURITY CLASSIFICATION OF:

$$
\text { a. REPORT }
$$

U b. ABSTRACT

U
OHWM

Ordinary high water mark

Stream classification

RACT

17. LIMITATION
OF ABSTRACT
None

18. NUMBER OF PAGES

50 19a. NAME OF RESPONSIBLE PERSON

19b. TELEPHONE NUMBER (include area code) 